\title{
Wind Turbines Offshore Foundations and Connections to Grid
}

\author{
Francisco Manzano-Agugliaro ${ }^{1, * \mathbb{D}}$, Miguel Sánchez-Calero ${ }^{1}$, Alfredo Alcayde ${ }^{1}$ (D), \\ Carlos San-Antonio-Gómez ${ }^{2} \mathbb{D}$, Alberto-Jesús Perea-Moreno ${ }^{3}{ }^{\mathbb{D}}$ and Esther Salmeron-Manzano ${ }^{4}$ \\ 1 Department of Engineering, University of Almeria, ceiA3, 04120 Almeria, Spain; \\ msanchezcal@iberdrola.es (M.S.-C.); aalcayde@ual.es (A.A.) \\ 2 Department of Cartographic Engineering, Geodesy and Photogrammetry, \\ Universidad Politécnica de Madrid, 28040 Madrid, Spain; c.sanantonio@upm.es \\ 3 Department of Applied Physics, University of Cordoba, CEIA3, Campus de Rabanales, 14071 Córdoba, \\ Spain; aperea@uco.es \\ 4 Faculty of Law, Universidad Internacional de La Rioja (UNIR), Av. de la Paz, 137, 26006 Logroño, Spain; \\ esther.salmeron@unir.net \\ * Correspondence: fmanzano@ual.es; Tel.: +34-950-015396; Fax: +34-950-015491
}

Received: 9 December 2019; Accepted: 15 January 2020; Published: 28 January 2020

\begin{abstract}
Most offshore wind farms built thus far are based on waters below $30 \mathrm{~m}$ deep, either using big diameter steel monopiles or a gravity base. Now, offshore windfarms are starting to be installed in deeper waters and the use of these structures—used for oil and gas like jackets and tripods-is becoming more competitive. Setting aside these calls for direct or fixed foundations, and thinking of water depths beyond $50 \mathrm{~m}$, there is a completely new line of investigation focused on the usage of floating structures; TLP (tension leg platform), Spar (large deep craft cylindrical floating caisson), and semisubmersible are the most studied. We analyze these in detail at the end of this document. Nevertheless, it is foreseen that we must still wait sometime before these solutions, based on floating structures, can become truth from a commercial point of view, due to the higher cost, rather than direct or fixed foundations. In addition, it is more likely that some technical modifications in the wind turbines will have to be implemented to improve their function. Regarding wind farm connections to grid, it can be found from traditional designs such as radial, star or ring. On the other hand, for wind generator modeling, classifications can be established, modeling the wind turbine and modeling the wind farm. Finally, for the wind generator control, the main strategies are: passive stall, active stall, and pitch control; and when it is based on wind generation zone: fixed speed and variable speed. Lastly, the trend is to use strategies based on synchronous machines, as the permanent magnet synchronous generator (PMSG) and the wound rotor synchronous generator (WRSG).
\end{abstract}

Keywords: offshore foundations; connection to grid; modeling; control

\section{Introduction}

The world's fastest growing energy source is wind energy [1]. Many countries have most of their wind farms onshore [2,3]. However, since 1947, more than 10,000 offshore platforms of various types have been constructed and installed worldwide. In 1995, 30\% of the world's crude production was made offshore [4]. For this reason, although still a bit far from this figure, the number of offshore windfarms represents a significant amount [5,6]. In this sense, the design and construction problems of offshore windfarm platforms are very similar to the ones that the oil and gas platforms have to deal with-even taking into account the additional port works, which have to be done in both cases $[7,8]$.

At the end of 2018, there was a cumulative installation in the offshore sector of around $20 \mathrm{GW}$ in Europe. Offshore wind capacity is expected to multiply by four over the next decade, as reported by [9]. 
The reason behind the current offshore windfarms developed thus far is based on the adapted technology used in the oil and gas industry. It is due to similar construction requirements in terms of distance to shore, huge cost of geotechnical campaign, as well as dependency of these offshore installation tools, which are very restricted and expensive [10,11]. In this sense, engineering, construction, and installation companies already working in the oil and gas industry have played a key role in the development of offshore windfarms [12].

Nevertheless, it is key to point out the difference between oil and gas and the offshore windfarm industry in terms of the cost incurred by each one. In this sense, the offshore wind industry cannot completely afford all techniques already implemented in the oil and gas industry; therefore, this industry must seek their own technical solutions based on the unitary cost reduction of the foundations, as well as benefit from a big scale production $[13,14]$. At an earlier stage, offshore windfarms were developed close to shore with shallow waters and with favorable technical conditions. In this scenario, foundations were installed up to 20 meters water depth, characterized by sandy sea beds, which allowed their driving into or laying down of gravity base structures $[15,16]$.

In recent years, due to the installation of offshore windfarms in deeper waters, as well as the increase of wind turbine's power, other structures like jacket and tripods have been used, i.e., in Alpha Ventus offshore windfarm [17-19].

Of those researched so far, it can be outlined that the cost of foundations increases significantly with depth, and therefore, the depth of the sea is the most crucial factor for the sustainability of offshore wind farms. For the exploitation of the wind energy resource, the depth of the sea is classified in three levels depending on its depth: shallow waters from 0 to $30 \mathrm{~m}$, transitional waters from 30 to $50 \mathrm{~m}$, and deep waters to more than 50 and generally up to $200 \mathrm{~m}$. Table 1 summarizes the water depths and expected of the different types of foundations of offshore wind farms. Fixed structures are considered suitable up to a maximum depth of $50 \mathrm{~m}$. Thus, it is assumed that there is a technical-economic barrier of about 40-50 m. Currently, above this depth, only floating structures are considered profitable.

Table 1. Summary of foundation types, depths, and use frequency.

\begin{tabular}{|c|c|c|c|c|c|}
\hline Foundation & Structure Type & $\begin{array}{l}\text { Water Depth } \\
\text { (m) }\end{array}$ & $\begin{array}{l}\text { Ground } \\
\text { Type }\end{array}$ & $\begin{array}{l}\text { Expected Depth } \\
\text { (m) }\end{array}$ & Current Use \\
\hline Monopile & Fixed & $<15$ & Sandy-clayey & 50 (with guy wire) & the most used \\
\hline $\begin{array}{c}\text { Gravity Base } \\
\text { Structure (GBS) }\end{array}$ & Fixed & $\leq 30$ & $\begin{array}{l}\text { Requires the previous } \\
\text { preparation of the } \\
\text { terrain. }\end{array}$ & $30-50$ & significant \\
\hline Jacket & Fixed & $>30(25-50)$ & $\begin{array}{l}\text { Different types of soils } \\
\text { (non-rocky) }\end{array}$ & $<50$ & significant \\
\hline Tripods & Fixed & $\approx 30$ & $\begin{array}{l}\text { Different types of soils } \\
\text { (non-rocky) }\end{array}$ & $>40$ & not common \\
\hline Semisubmersible & Floating & $>60$ & - & $>60$ & not common \\
\hline Spar-buoy & Floating & $>60$ & - & $>120$ & not common \\
\hline $\begin{array}{c}\text { Tension Leg } \\
\text { Platform (TLP) }\end{array}$ & Floating & $>60$ & - & $>100$ & not common \\
\hline
\end{tabular}

\section{Main Typologies of Direct or Fixed Structures}

The cost of support structures is approximately 35\% of the total cost of offshore wind facility projects, and foundations are key aspects for their future development [20]. Main typologies of foundations used in the wind farms erected so far are monopiles, gravity base structures (GBS), jackets, and tripods [21]. Key characteristics of these structures are described below, as seen in Figure 1. 


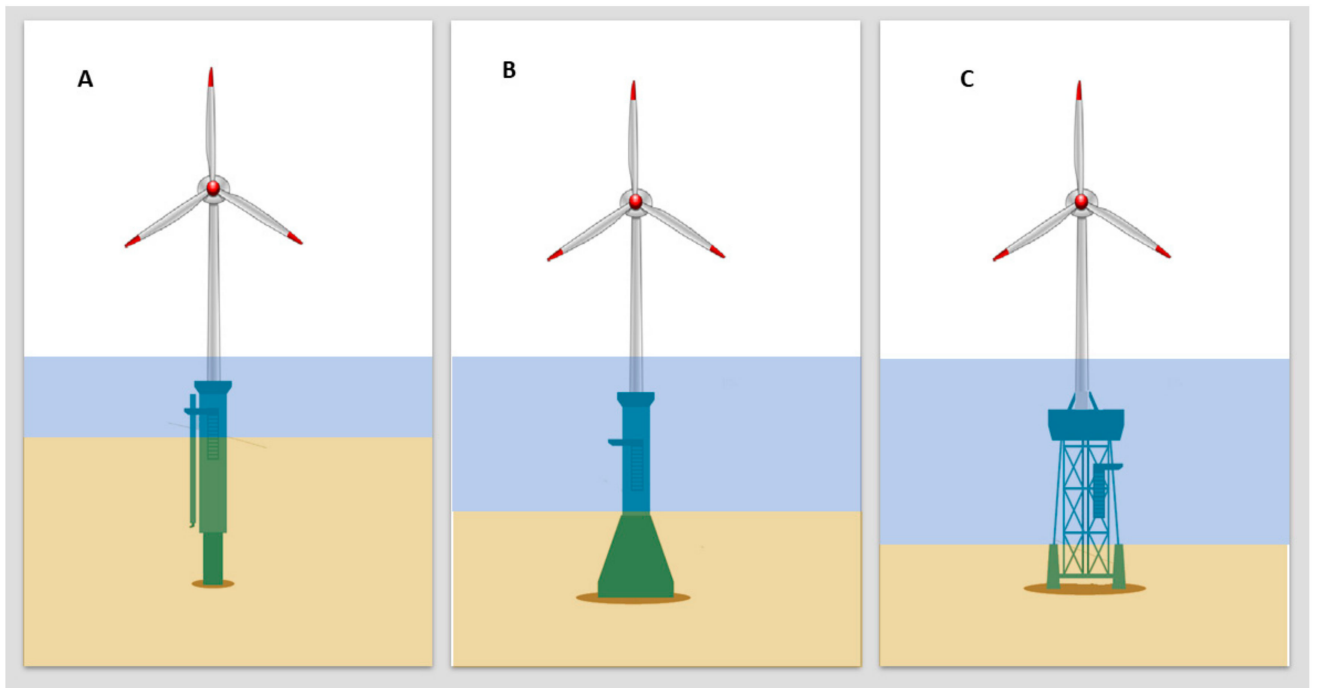

Figure 1. Fixed foundations: (A) Monopile. (B) Gravity. (C) Jacket.

\subsection{Monopile}

In addition to their apparently conceptual simplicity, monopile foundations, seen in Figure 1A, are far from the usual standards of onshore engineering. This is mainly due to their size and usage of a transition piece between the pile and wind turbine tower [22,23].

Piles used so far can reach up to $5 \mathrm{~m}$ diameter with a weight above $600 \mathrm{t}$ and thickness around $100 \mathrm{~m}$ where suitable $[20,24]$. Their installation requires jack up vessels with enough cranage power to lift these piles, as well as with a hammer which can allow their driving into the seabed working from below sea level. In Figure 2, some details of the described installation process can be seen.

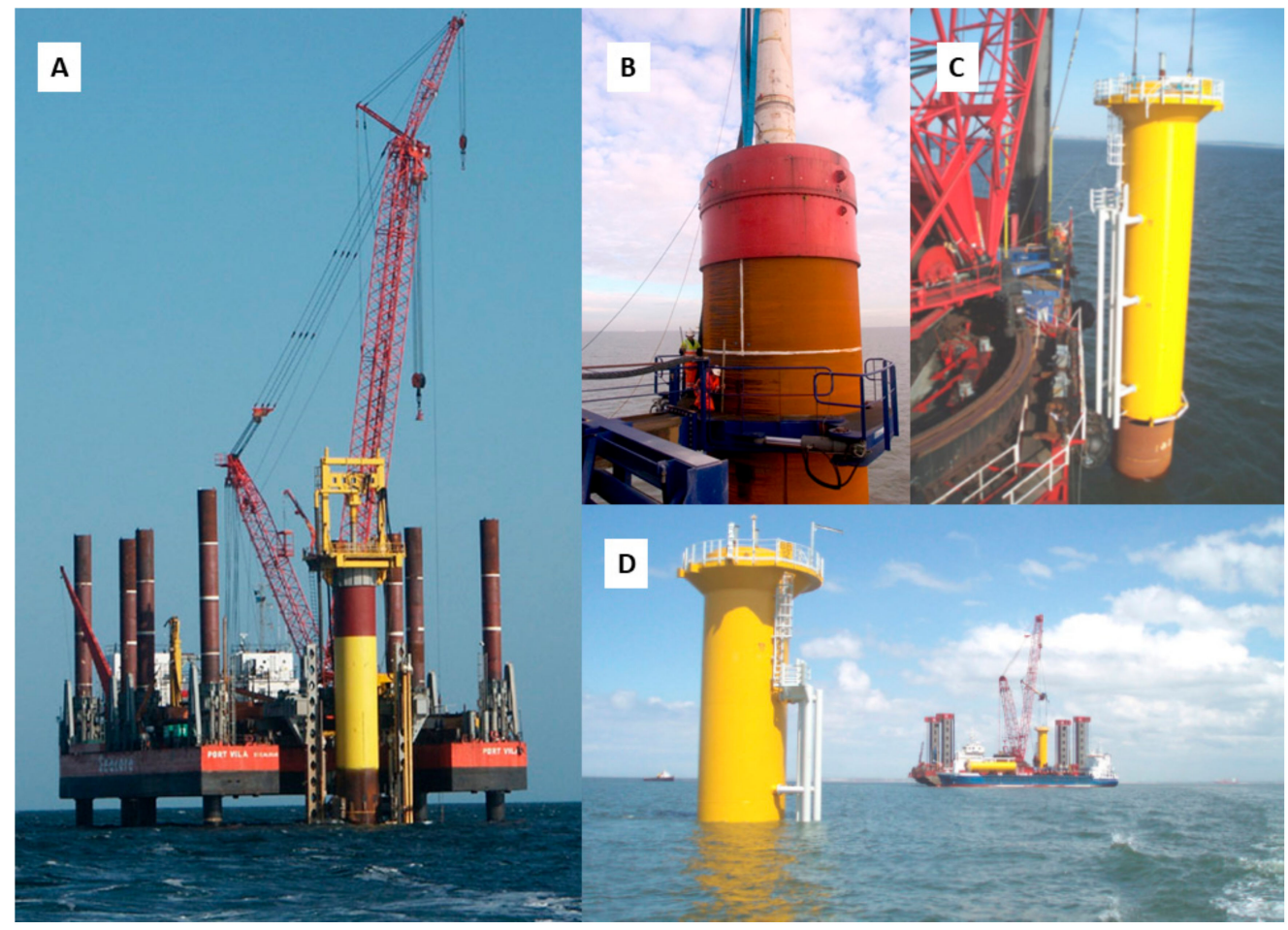

Figure 2. (A) Jack-up during a monopile installation at North Hoyle (UK). (B) Drilling of a monopile. Kentish Flats (UK). (C) Transition piece installation. (D) Monopile installation finished. 
The transition piece, which covers the pile along $1.5-2 \mathrm{~m}$, is connected to the pile through an epoxy resin grout of above $100 \mathrm{MPa}$ resistance to simple compression [25]. This transition piece has a double purpose: leveling the structure, allowing the verticality of the wind turbine tower, and secondly allowing the installation of the boat-landing as well as j-tubes and anodes [26,27].

At present, it seems that the limit for the installation of monopiles is around $30 \mathrm{~m}$ depth, as indicated by Rüdiger (2013) [28]. In a theoretical sense, the development of new hammers with larger diameters could allow the installation of monopiles at greater depths. On the other hand, considering the substantial weight gain that this represents, it would not be a valid economic option [29-31].

Monopile foundation research started in 2001 [32], reaching a maximum output in 2015 with 105 documents published in the Scopus database. By country, this technology was led by UK with 95 publications, followed in second place by Denmark (88) and third place is by the USA and Norway (68). Most of this research was published on conference proceedings (56 \%) instead of articles, which only represented $40 \%$ of the scientific output. The institutions which were more productive in the research of monopiles were Norges Teknisk-Naturvitenskapelige Universitet (Norway), Aalborg Universitet (Denmark), Danmarks Tekniske Universitet (Denmark), Vrije Universiteit Brussel (Belgium), and Delft University of Technology (Holland). The main keywords representing the topics related to this research field are: finite element method [33], soils [34], structural design [35], and support structures [36] or electric utilities [37].

\subsection{Gravity Base Structure (GBS)}

For those sites where ground conditions are good enough to support high pressures transferred from these structures, the gravity base could be a very competitive solution [38]. Basically, these are concrete-made structures, fabricated in a closer port to the final installation location where they sit on rockfill or loose stone and are protected against scour [39-41]. This means that these structures require important ground preparation prior to their installation. To protect these structures from tidal and current effects, they are shaped with most of the weight concentrated on their base, leading to a smaller diameter at sea water level [42,43]. Some details of the GBS parts are shown in Figures 1B and 3.

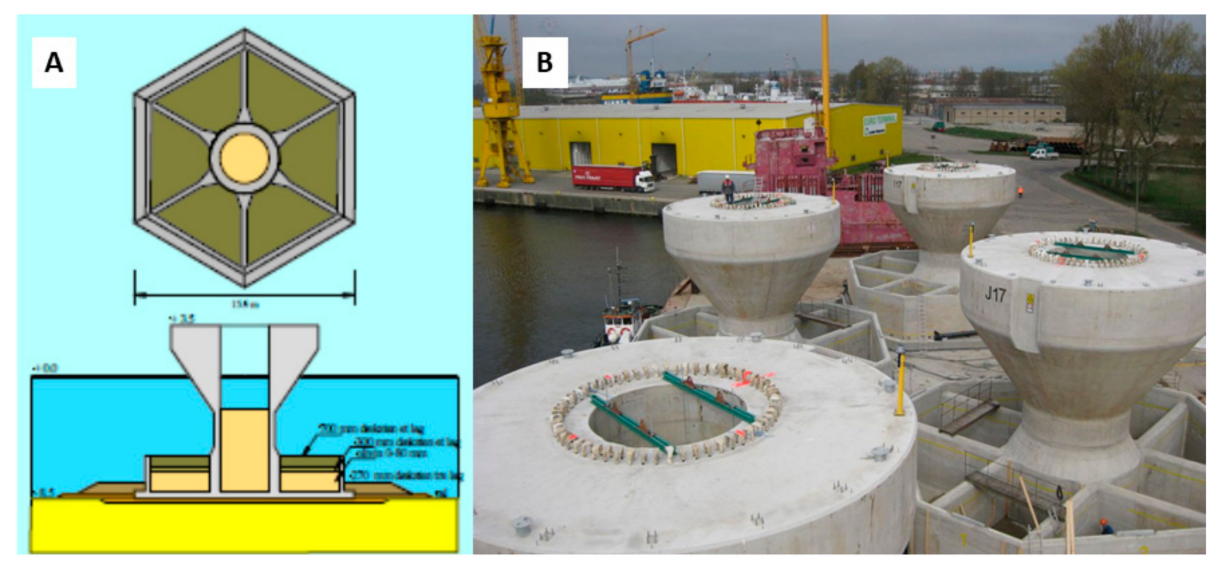

Figure 3. (A) Gravity base structure (GBS) at Nysted (Denmark). (B) GBS ready for transportation "Rodsand 2" (Denmark).

The use of this kind of structures has been limited so far to water depths below $15 \mathrm{~m}$ due, as pointed out by Winkler and Ole Stromme (2014), to their huge weight and need for very powerful lifting and installation means [44].

Nevertheless, at the Thornton Bank wind farm-located in Belgium—gravity base structures have been used at $30 \mathrm{~m}$ drafts. This experience has proven this kind of structures are very restricted by installation tools due to their huge weight, which leads to a higher cost than expected [45]. Nevertheless, it seems clear that gravity base structures still have wide room for improvement. This will be mainly on the installation activities; in this sense, they have to reduce their large dependency on installation 
vessels as well as go for wider installation windows. To achieve that design for water depths higher than $20 \mathrm{~m}$, we must be focused on weight reduction during transportation, taking advantage of their floating capacity [39-41].

On the other hand, these structures have the advantage of being simple concrete structures, which can be constructed by a big number of construction companies. Based on that advantage, there are many investigations whose main target is to optimize this kind of structures to be used for the offshore wind industry [44].

Skirted gravity base foundations and suction caisson foundations are considered as viable alternatives to monopile foundations for offshore wind turbines [46]. Research in this field started in 1982 by Dixon (1982) in a conference proceeding [47]. However, further research in this field has not been very prolific, being led by Germany, the United States, and the United Kingdom. One of the most important research fields related to this topic can be considered the effect of dynamic soil-structure interaction on the rotation of the foundation [48], and predicting the long-term accumulated angular rotation [46]. Additionally, it is interesting to mention that this research in mainly linked to Arctic engineering [49]. Today, some authors highlight the advantages of the GBS concept in deeper locations [20].

\subsection{Jacket Foundation}

These are tubular base structures widely used in the oil and gas industry. As they are made of small diameter tubes, they have a lower till and current exposure, which makes them suitable for severe marine climatic conditions [50].

Jacket foundations used so far for the offshore wind farm industry are based on a four-leg structure, where each of them is fixed to ground through a pile of between 1 to $2 \mathrm{~m}$ of diameter which allows transfer of loads from the structure to ground. Figure $1 \mathrm{C}$ and Figure 4 show a scheme of this structure.
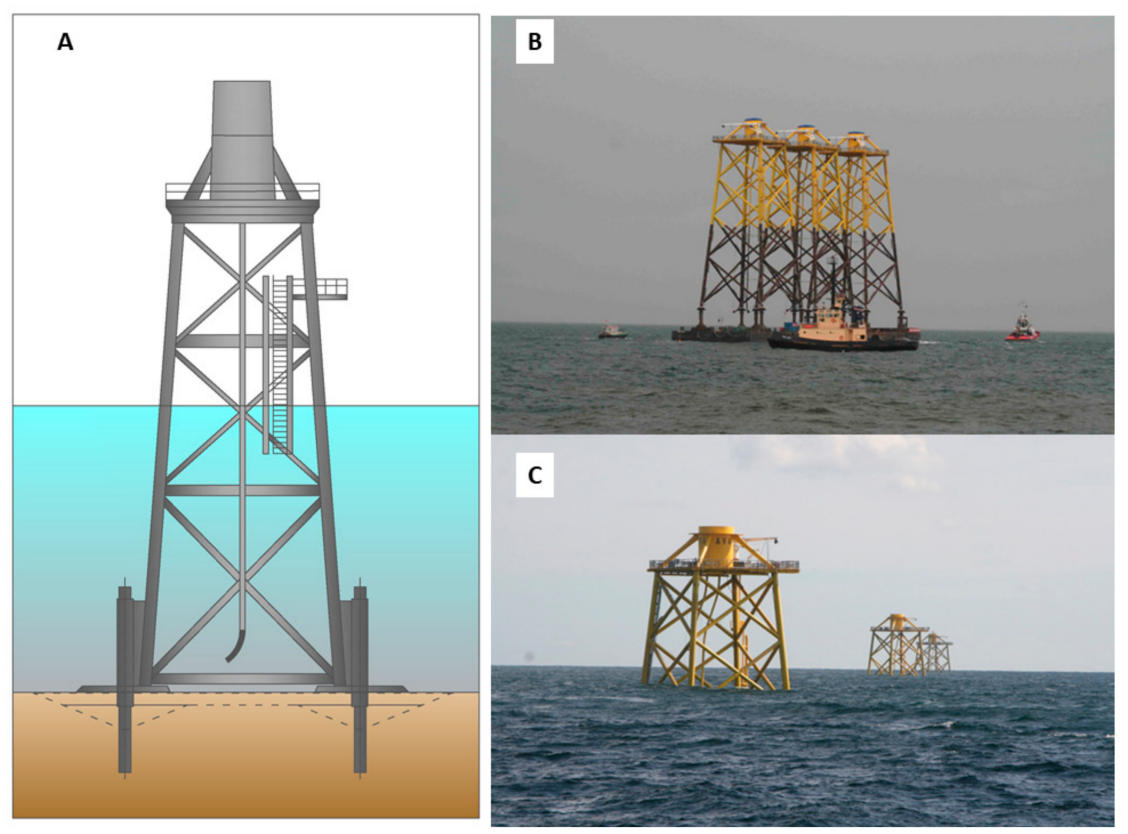

Figure 4. Jacket structure. (A) Scheme, based on [51]. (B) Jacket foundation transportation (Alpha Ventus wind farm). (C) Jacket foundations installed (Alpha Ventus wind farm).

To date, only two offshore windfarm projects have been developed based on this kind of structures: "Beatrice" in Scotland, where two jacket foundations units were installed at around $45 \mathrm{~m}$ depth, and "Alpha Ventus" in Germany, where six jacket foundations were constructed for up to $30 \mathrm{~m}$ depth. In both cases, the wind turbine Repower $5 \mathrm{MW}$ was selected to be placed on top of these jacket foundations through respective towers, which is one of the heaviest wind turbines available on the market $[52,53]$. 
Research on this technique can be understood to have begun in 2006, comparing this type of foundation with others, such as the simple monopile or gravity concepts [54]. However, the research was not disseminated until 2010, when it was shared widely thanks to a series of specific conferences in this field. Attendance this was led first by Germany, followed by Norway, the United States, the United Kingdom, South Korea, and China. The leading institution in the field was Norges Teknisk-Naturvitenskapelige Universitet (Norway), followed by Gottfried Wilhelm Leibniz Universitat (Germany) and Aalborg Universitet (Denmark). It is remarkable that this research topic is also related to Arctic engineering, supported by the Conferences on Offshore Mechanics and Arctic Engineering.

There are other projects still under development based on water depths around 30 to $40 \mathrm{~m}$, for which it seems clear that the best foundation type to be used is jacket foundation. For this kind of water depths, the weight of a jacket foundation is quite a bit lower than that of a monopile foundation; hence, although the manufacturing of a jacket foundation is significantly more complex as well as more expensive, it is still a competitive solution which could be expected to be used for up to 50-60 m water depths [55]. Based on that, the jacket foundation could be seen as one of the more robust solutions for the development of offshore wind farms in the short term, and there are several installation companies working right now on the design of specific vessels to improve the handling of this kind of structures which will allow for a better installation efficiency as well as for a reduction in the overall cost of the foundation $[56,57]$.

\subsection{Tripods}

Tripods keep a central column under a wind turbine tower following the same structure as that of a monopile, but connected through a tubular structure to three lower legs where piles will be placed, which will transfer load to the ground in the end [58]. This structure combines the structural function of a jacket foundation, as a triangular structure, with that of the monopile, keeping a core with great resistance to flexion [59]. Figure 5 shows a scheme of a tripod structure.

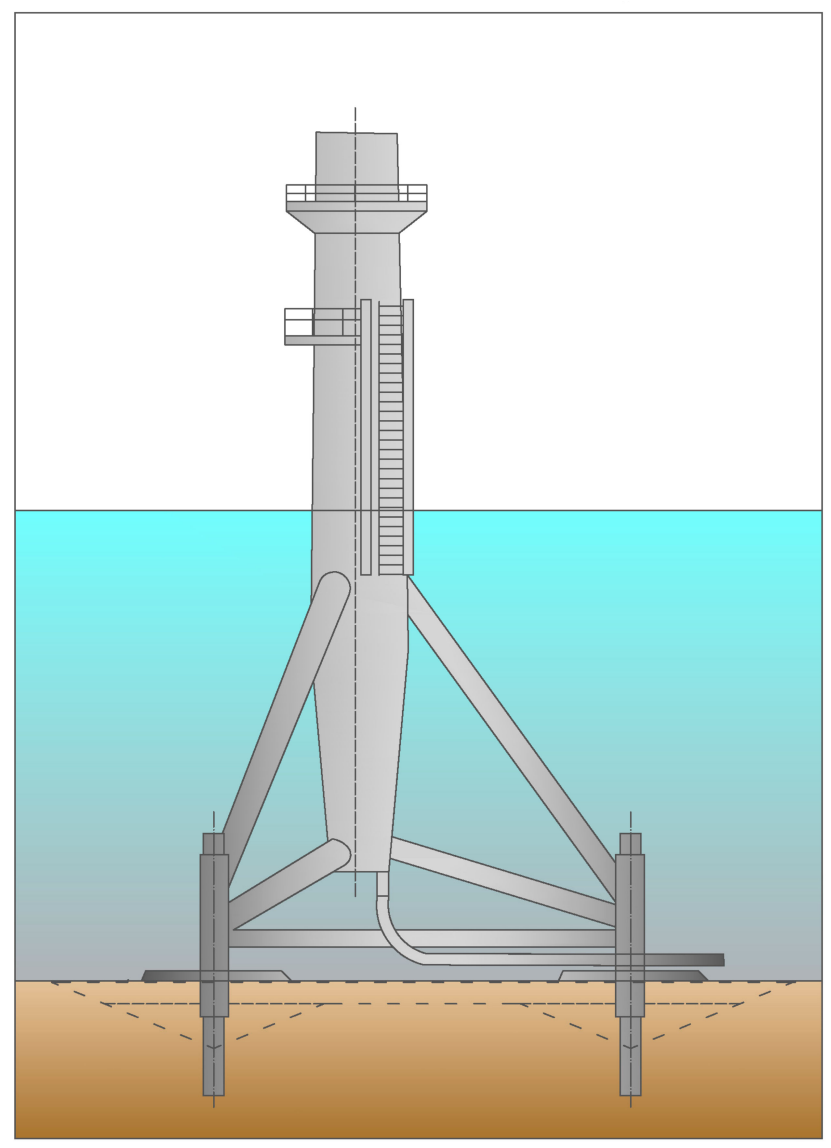

Figure 5. Tripod structure scheme, based on [60]. 
While tripods used in "Alpha Ventus" to support 5 MW Multibrid wind turbines weigh around $700 \mathrm{t}$ each, jackets used in the same project to support 5 MW Repower wind turbines weigh around $500 \mathrm{t}$, which is an important structural advantage for tripod foundations [61]. To the extent that it is possible to optimize the tripod foundation, its cost will get closer to that of jacket foundations, since tripod fabrication is simpler than that of a jacket foundation due to the lower number of joints, as well as the fact that it requires one less pile, with consequent savings during installation [62].

This is why it can be foreseen that the tripod foundation could be a very competitive alternative in the following years for those locations where water depth is above $40 \mathrm{~m}$ [58]. In Figure 6, we can observe a Tripod foundation transportation and installation, as well as a general view of both types of foundations (jackets and tripods) installed at an Alpha Ventus windfarm project.

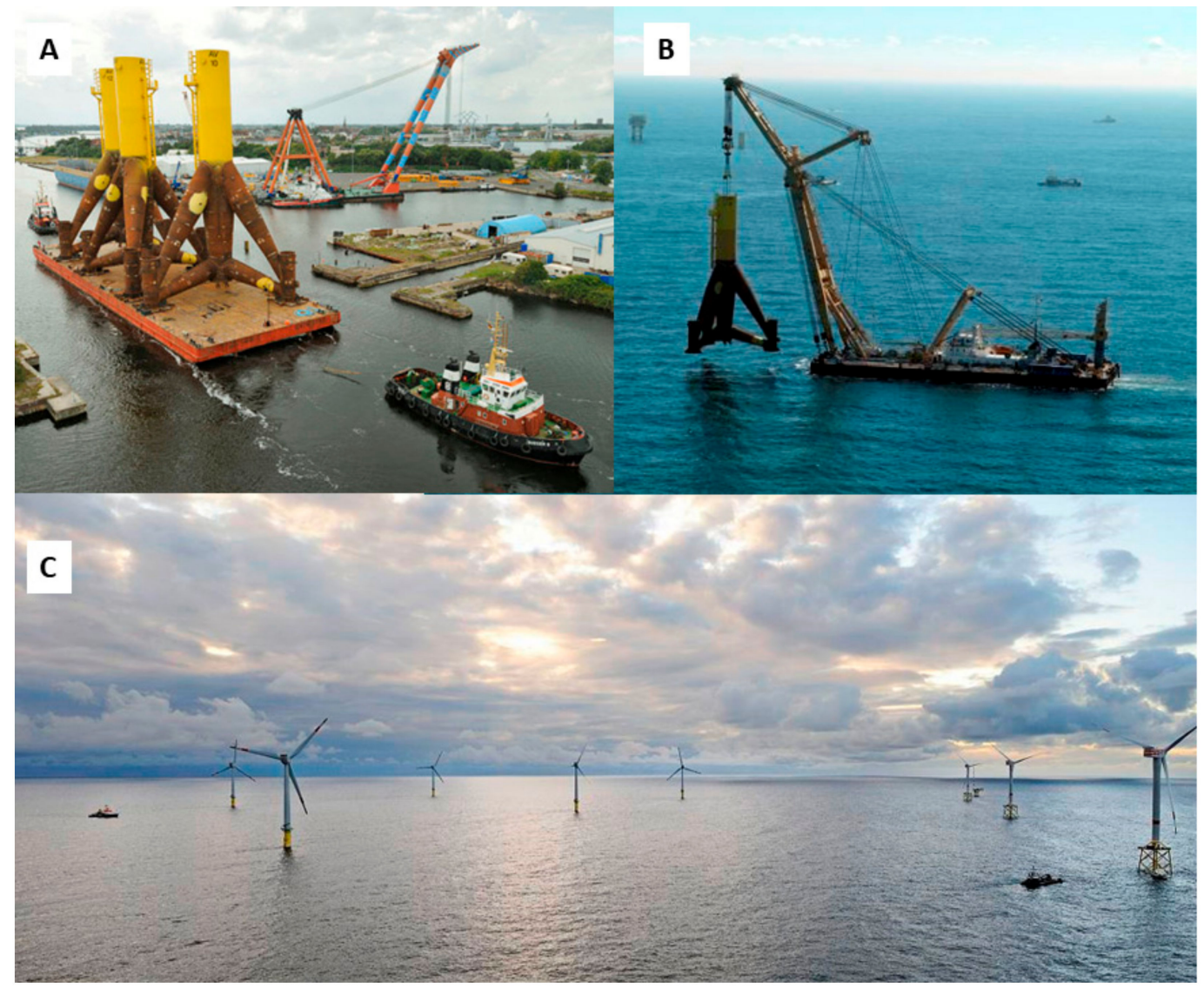

Figure 6. Alpha Ventus windfarm. (A) Tripod foundation transportation. (B) Tripod foundation installation. (C) Jackets (right side) and tripod (left side) foundations installed.

\section{Other Types of Fixed Structures}

The offshore wind turbine industry is still at an early stage, with a lot of room for improvement as well as for technical and economical optimization [63]. In recent years, a lot of new structural concepts have been developed, aiming for one of the following targets [63]:

- Dependency reduction from installation means;

- Extension of the installation window;

- Cost reduction thanks to big-scale production;

- Lower dependency from cost of steel;

- Adaptation to deeper waters;

- Improvement of offshore site conditions with a reduction of the installation period. 
Within the next subchapters, several concepts under development are presented, which in the future could be real alternatives from previously described typologies.

\subsection{Tripile}

Developed by "Bard Engineering", the prototype has already been installed in offshore sites, and this technical solution is backed up by a contract for the installation of $400 \mathrm{MW}$ in the German North Sea [64]. An overview of this prototype can be seen in Figure 7. In summary, this structure is built up of three vertical piles set into a cross-shaped platform over which the tower of the wind turbine is placed. This structure works as a portico with rigid knots in the upper part, allowing pile flexion reduction; therefore, the piles' diameter could be below $3 \mathrm{~m}$ [65].

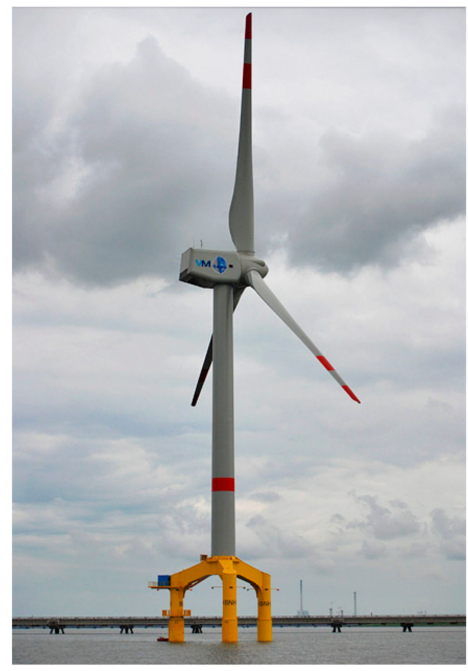

Figure 7. Bard $5 \mathrm{MW}$ wind turbine over a tripile foundation.

\subsection{Monopile Suction Bucket}

This concept was developed by "Ballast Nedam", a company which has a wide proven experience within the offshore foundations' installation field [66]. Basically, this consists of a concrete pile set up with prefabricated concrete segments. Its installation is done through drilling along the inside of the pile, which is driven into the ground while drilling moves down forward [67]; see Figure 8. Below, an example of this kind of structure installed in the German Baltic sea for a $5 \mathrm{MW}$ wind turbine at around $30 \mathrm{~m}$ depth is presented [68,69]:

- External diameter: $6900 \mathrm{~mm}$;

- Thickness: $700 \mathrm{~mm}$;

- Lowest level: $-61.00 \mathrm{~m}$;

- Upper level +3.50 m;

- Passive mass: $65 \mathrm{~kg} / \mathrm{m}^{3}$;

- Active frame: 37 tendons with 22 wires of $15.7 \mathrm{~mm}\left(0.6^{\prime \prime}\right)$;

- Weight: $2200 \mathrm{t}$. 


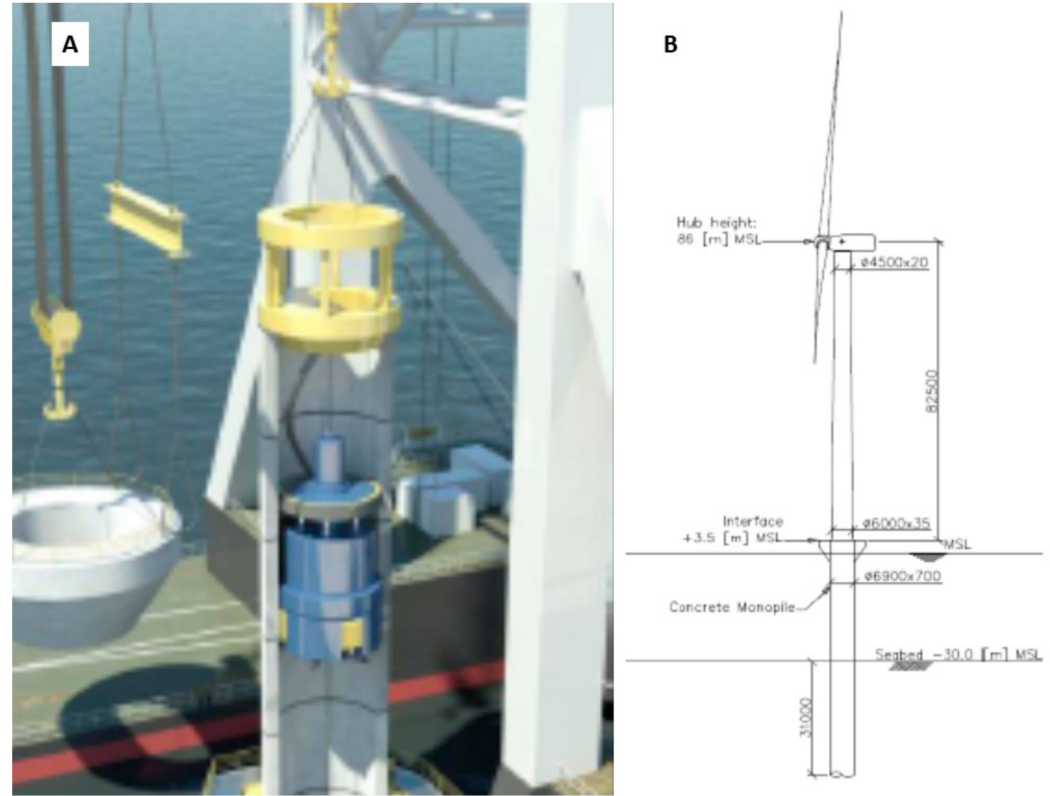

Figure 8. Monopile suction bucket. (A) Installation. (B) Scheme.

\section{3. "Zublin" Gravity Base}

It is a gravity base foundation made up of a cross-shaped box based on four legs and made of pre-tensed steel, which lies down over the ground [70]. In this case, the ground only requires minimum preparation for the installation of this structure. A scheme of this structure can be seen in Figure 9. The main characteristics of this foundation are as follows [71]:

- Easy fabrication, although its installation is quite complex due to its weight;

- Suitable for water depths of around $40 \mathrm{~m}$;

- No cathodic protection against corrosion required;

- Lower dependency from steel cost;

- Easy to dismantle.

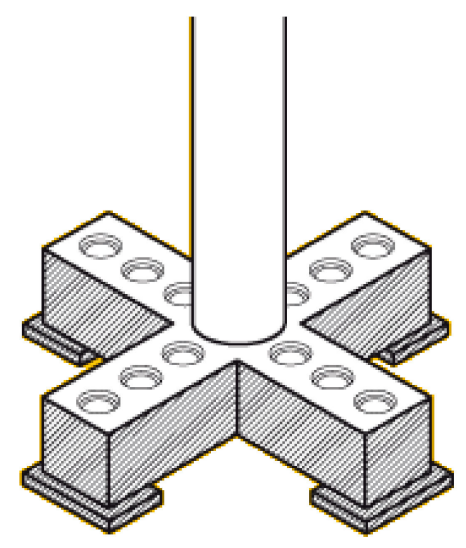

Figure 9. Züblin gravity base.

\section{Floating Structures}

Floating structures are neither a technically nor economically viable solution yet. Nevertheless, research on these solutions is very active today in a few remarkable projects, even more when "near-shore" projects are no longer available and it comes to exploring deeper waters ( $>50 \mathrm{~m}$ depths). 
As per the fixed structures case, these new developments are inspired by the evolution of floating structures coming from the oil and gas experience [72-74]. Figure 10 shows a representation of the floating structures used in the oil and gas industry.

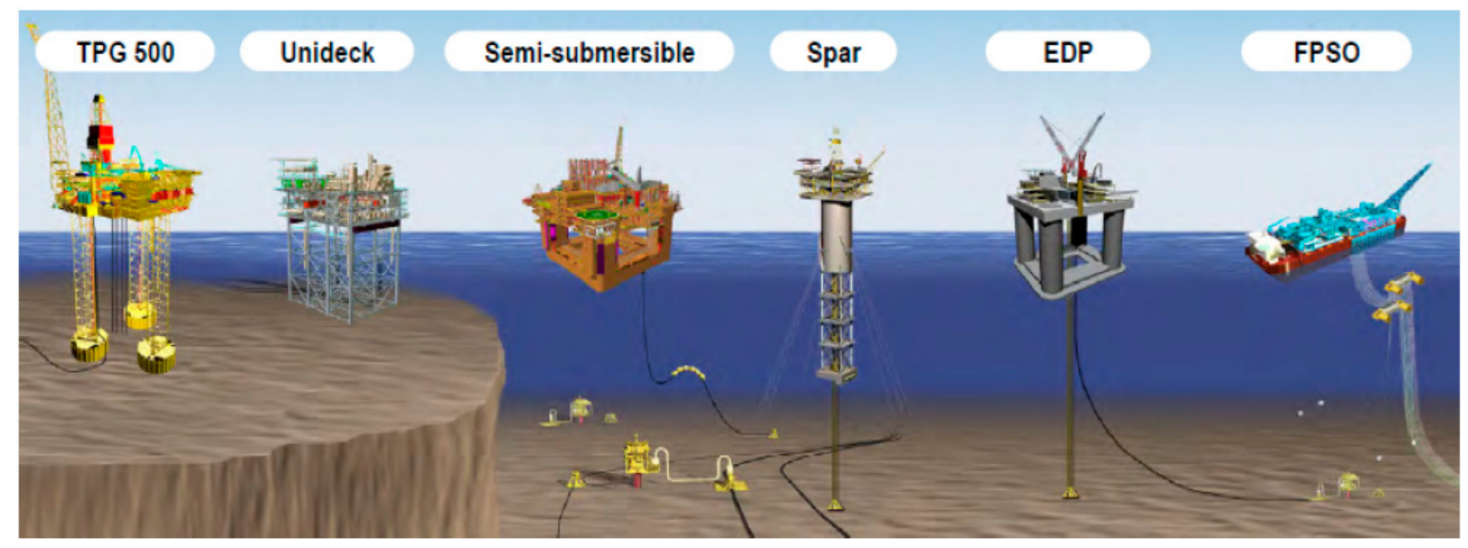

Figure 10. Typical floating structures used in the oil and gas industry [51].

Due to the relatively fast development the offshore wind industry has experienced in recent years, moving from 3-4 GW figures early in the 21st century to contemporary figures of about $12 \mathrm{GW}$, and bearing in mind the market forecast reaching up to levels of 40-50 GW by 2020 as per information published by the Carbon Trust organization on their webpage, it is logical that the offshore industry would have to study new alternatives for future projects, which it will be necessary to instal far from currently near-shore layout projects $(<50 \mathrm{~km})$ once these scenarios are exhausted [75-77]. To make floating structures a reality, several aspects, both cost-competitiveness and technical reliability, must be overcome [78].

From a cost point of view, due to the investment effort required to move from currently floating "demonstration" projects to commercial ones, it is not only private investment that would be required but also and mainly government support, at least for the early phases of this transition. On the other hand, due to the technology itself of the floating structures, the installation and open costs are lower rather than for fixed structures, since most of the whole structure could be assembled directly at the dock, avoiding the huge costs coming from the installation vessels (limited due to their current availability as well as weather downtime due to bad weather conditions) $[79,80]$.

From a technical point of view, it is clear that floating structures still have some problems to be re-engineered on the dynamic behavior of their structures, catenary mooring lines, anchoring, etc. [75-77]. Although there are a lot of branches or derivations, there are mainly three core floating wind types of foundations [81], see Figure 11:

- Semisubmersible;

- Spar-buoy;

- Tension leg platform (TLP).

Before getting into the description of the main floating foundations named above, it would be interesting to draw our attention to the fact that the configuration of the Spanish coast, where depths are very high next to the shoreline, would be very favorable to this kind of foundations, but massive development of the offshore wind turbine industry in Spain, beyond 3000 to $5000 \mathrm{MW}$, using direct or conventional foundations, would be only possible if these floating structures reach enough maturity to be economically viable [5]. 


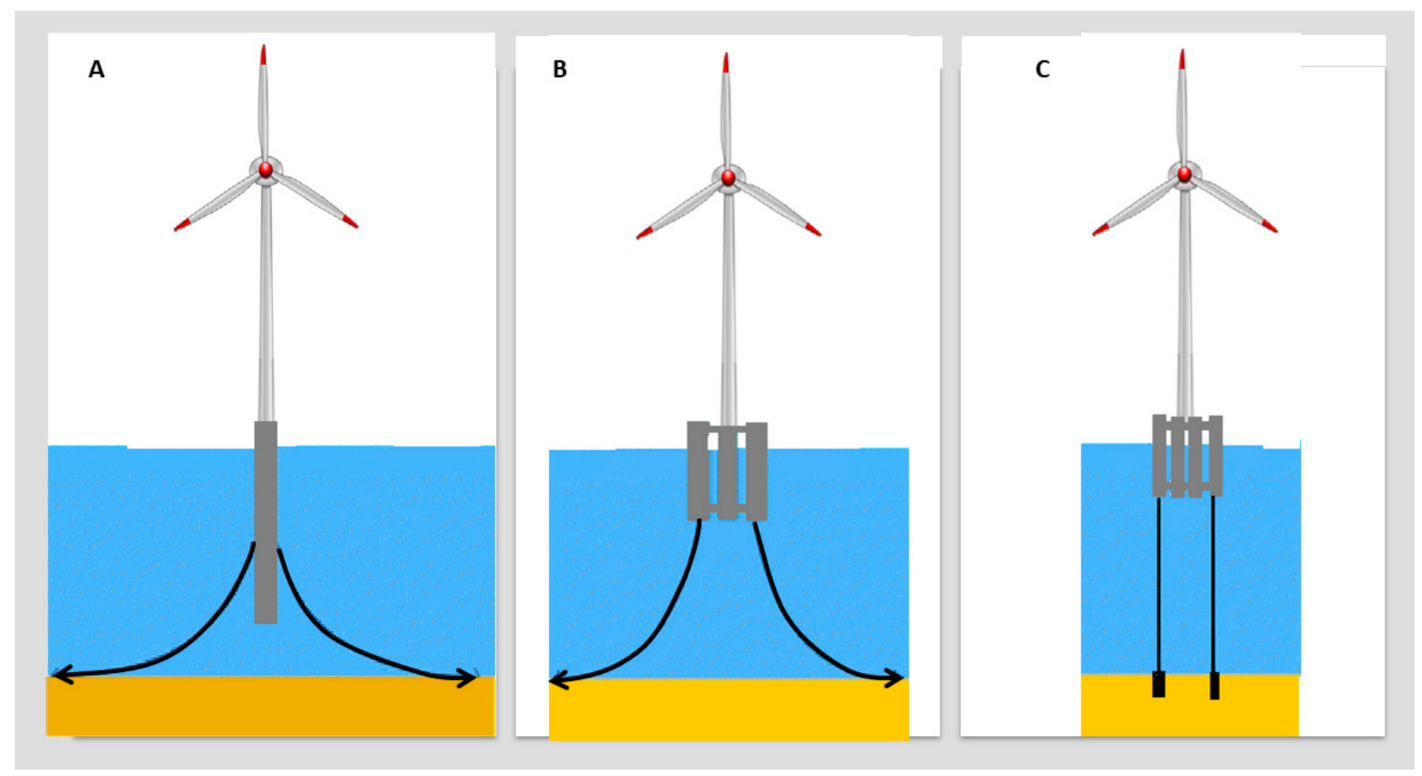

Figure 11. Floating wind foundations typologies [76]. (A) Spar-buoy structure. (B) Semisubmersible. (C) Tension leg platform (TLP).

In the following pages, a description of the most important concept and prototypes developed is reported:

Research on floating structures related to wind turbines started in 1988, when Bauer (1988) used for this concept the term of island [82]. However, important scientific production did not begin until 2007. Technologies for floating foundations for offshore wind turbines have evolved from then, and a very good review of them is offered by Roddier et al. (2010) [83]. Research on this technology is led by the United States, followed by China, Norway, the United Kingdom, and South Korea. In terms of institutions, Norges Teknisk-Naturvitenskapelige Universitet (Norway) is the leader, followed by Danmarks Tekniske Universitet (Denmark), Cranfield University (UK), National Renewable Energy Laboratory (USA), and Shanghai Jiaotong University (China). The main topics related to this technology are mooring [84], hydrodynamics [85], dynamic response [86], and aerodynamics [87].

\subsection{Semisubmersible}

A semisubmersible is a structure which remains semisubmerged on the sea, being stabilized through catenary mooring lines anchored to the seabed. The main problem with this kind of structure is its need for a heavy structure with high mass to provide enough stability; on the other hand, wind turbines' offshore installation is easier from this kind of structure due to its high level of stability [88-91].

An example of this type of floating foundation is the Windfloat project. This is a project which wasinstalled off the coast of Portugal in 2011 and is powered by a $2.3 \mathrm{MW}$ wind turbine and based on a 3 column semisubmerged structure moored to the seabed with three catenary lines [92,93].

The research related to semisubmersibles is led by the United States followed by Norway and Spain. The main institutions are the University of Maine (USA), Norges Teknisk-Naturvitenskapelige Universitet (Norway), Instituto Superior Tecnico (Portugal), and National Renewable Energy Laboratory (USA). Just as for floating structures, some of the main research topics are mooring [94], dynamic response [95], and hydrodynamics [96].

\subsection{Spar Type Wind Turbines}

These are cylindric structures which are also anchored to the seabed through a catenary mooring line. Their main difference from semisubmersible structures is that they come along with a lighter but longer structure which comes with a lower center of gravity $[97,98]$. On the other hand, this advantage 
in terms of design could also be seen as a disadvantage when it comes to draft depth, requiring deeper waters than semisubmersible ones do, which could lead to more expensive projects [99,100].

In terms of installation, it is important to note that due to issues with stability during wind turbines' assembly, these kinds of structures are challenging and would require the use of heavy lifting cranes (with high daily rates as well as subject to weather downtime) rather than a more accessible concept than semisubmersible structures [101,102].

An example of this type of foundation is the Hywind and Sway project. This is a project which was installed off the coast of Norway in 2009 and is powered by a $2.3 \mathrm{MW}$ wind turbine and based on cylinder structure moored to the seabed with three catenary lines [103]. The top five countries conducting research on this technology are Norway, China, the United States, South Korea, and Japan, and the top institutions are Norges Teknisk-Naturvitenskapelige Universitet (Norway), Danmarks Tekniske Universitet (Denmark), and Pusan National University (South Korea). For the parked floating wind turbines of a spar type concept, one of the main lines of research is the determination of extreme responses for design checks, considering coupled wave and wind-induced motion and structural response in harsh conditions $[104,105]$.

\subsection{Sway}

The sway structure is based on a continuous tower anchored to the seabed through a mooring connector. The prototype was installed off the coast of Norway in 2011 and is powered with a $0.15 \mathrm{MW}$ wind turbine [106].

\subsection{Tension Leg Turbine Platform (TLTP)}

The tension leg turbine platform is considered a method for accessing offshore wind resources in moderately deep water [107]. The structure as per Moon and Nordstrom (2010) consists of a minimum of three submerged arms. Later, this multiarm structure is anchored to the seabed through the same number of tension legs [108].

As with the spar-buoy structures described above, we are facing a lot of challenges during the wind turbines' installation due to stability issues. On the other hand, TLP structures could mean a very competitive alternative for deep waters [108-111].

An example of this type of foundation is the Pelastar project, a five-arms submerged structure anchored to the seabed through five tension legs. This foundation is empowered with a $6 \mathrm{MW}$ wind turbine [112].

\section{Wind Farm Connections to Grid: An Overview}

Usually, the wind turbine produces electric energy in low voltage (LV). The most common voltage for these facilities is 690 volts [113]. Today, the most common solution for the facilities is to connect the generator output to power electronics; in this way, it can work with an extended range of wind speeds, increasing or decreasing the speed of the wind turbine while wind speed increases or decreases. This also allows rapidly increasing or decreasing the dispatch of energy to the grid to deal with fluctuations. However, this system has its drawbacks; the use of this electronics implies a higher cost of control and maintenance in front of fixed speed wind turbines. Since the appearance in the market of this type of solutions, year after year, they are continuously imposed on the solution of fixed speed.

Another important change of trend is the elimination of gearboxes that couple the generator to the blades by direct-drive motors that connect directly to the blades. The advantages of this system are clear: (I) there is a greater availability of space in the installation when removing the gearboxes, (II) the space and weight of the installation is reduced, and (III) this consequently allows increasing the capacity of the generator without penalizing too much the foundation, which is very important in offshore wind farms.

Once the electricity is generated at the output of the generator, the main problem is the connection to the grid. Today, the most common solution is to place a $690 / 30 \mathrm{kV}$ transformer and carry the energy 
in high voltage (HV) through the grid and until the arrival of the substation [114], for its transformation into medium voltage (MV), thus minimizing energy losses in the transport [115,116].

The design of an offshore wind farms usually focuses on the design and placement of wind turbines [117-119], moving the design of the substation [120], which carries a significant percentage of the cost of installing the wind farm, to the background, since, as a rule, the cost of the substation is approximately $5 \%$ of the total investment of the facility. As an example, the Wikinger offshore wind farm, inaugurated in October 2018 with an installed capacity of $350 \mathrm{MW}$, cost 1.4 billion euros. There are technical solutions such as that proposed by $\mathrm{Li}$ (2008) [121], which, using a genetic and immune hybrid algorithm, seek to obtain the best solution to minimize cost while increasing performance, depending on the number of substations (capacity, type, and number of transformers) and the connections between wind turbines and substations. It is important to keep in mind that the cost of the substation is a very important part of the total cost of the facility, but also that it must keep in mind the useful life of the substation, and this could affect the design. As an example, it is much more economical to locate the substation on land rather than sea, but this decision may not always be optimal for certain facilities. The trend is leading to locating offshore substations near the generation (see Figure 12) since transport losses are minimized by delivering at $132 \mathrm{kv}$ instead of $30 \mathrm{kV}$; this also reduces the cost of the dispatch to the grid, since the tendency is to implant farther from the coast, due to several conditioning factors. Thus, if a practical example is made for a wind farm of 100 wind turbines of $2 \mathrm{MW}$ connected to a substation, this means $200 \mathrm{MW}$ installed. This makes the connection with land at $8000 \mathrm{~m}$ of link distance to land, and it has been considered a power generation at full load of 2628 hours per year. The losses and cost are summarized in Table 2. It can be seen that it is 5 times lower in the $132 \mathrm{kV}$ connection if it is considered the cost of $50 € \mathrm{MWh}$.

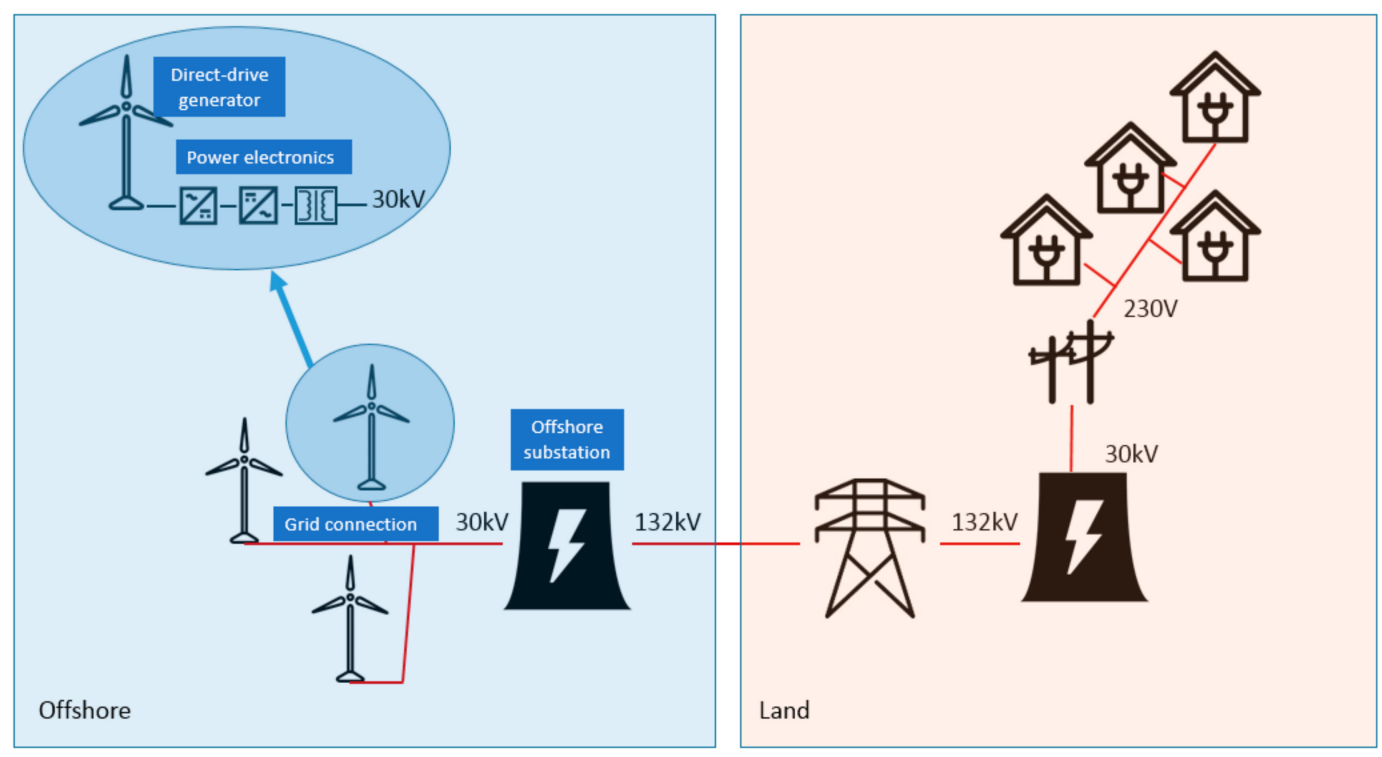

Figure 12. Scheme of generation and transport of energy from offshore wind farms.

Table 2. Example of power and economic losses as a function of the grounding voltage (50€ MWh).

\begin{tabular}{ccccccc}
\hline $\begin{array}{c}\text { Voltage } \\
(\mathbf{k V})\end{array}$ & $\begin{array}{c}\text { Current } \\
(\mathbf{A})\end{array}$ & $\begin{array}{c}\text { Wire Section } \\
\left(\mathbf{m m}^{\mathbf{2}}\right)\end{array}$ & $\begin{array}{c}\text { Weight } \mathbf{C u} \\
(\mathbf{T})\end{array}$ & $\mathbf{k \in / k g} \mathbf{( C u )}$ & $\begin{array}{c}\text { Losses } \\
(\mathbf{M W})\end{array}$ & $\begin{array}{c}\text { Losses } \\
(\mathbf{\epsilon} / \text { year) }\end{array}$ \\
\hline 30 & 3849,00 & $3 \times(4 \times 800)$ & 4694 & 33,330 & 1,900 & 249,660 \\
132 & 874,77 & $3 \times 800$ & 1174 & 8332 & 0,393 & 51,583 \\
\hline
\end{tabular}

In addition, Figure 13 shows the limitations for the Spanish coast. Red zones are areas protected by Spanish legislation, either for environmental, military or tourist reasons, while the yellow ones must 
be studied by the different administrations, and only the green ones are suitable in advance. Thus, these restrictions are driving even major investors in wind farms to design underwater substation pods.

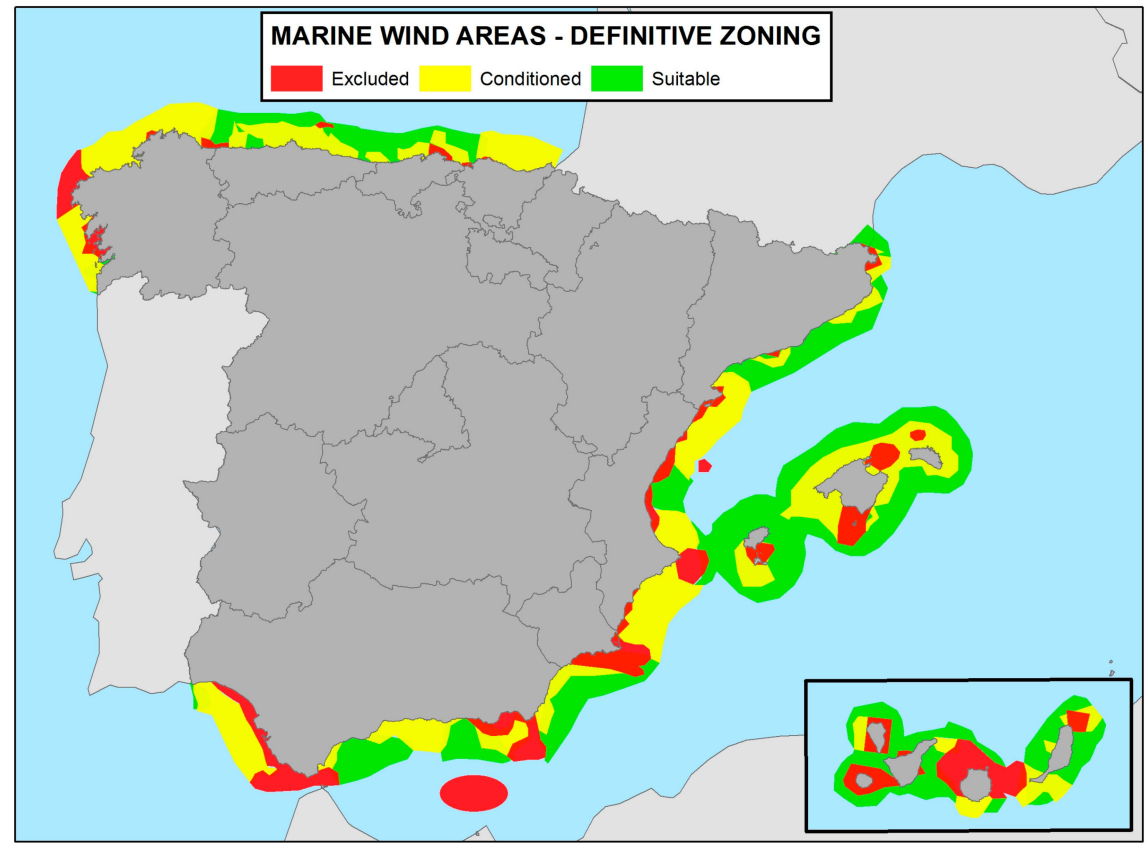

Figure 13. Areas for wind farms location on the Spanish coast, based on [122].

Regarding the design of the grid, it can be found from traditional designs such as radial [123], star [124] or ring [125] type, to complex designs based on sophisticated mathematical techniques that use different algorithms to obtain the optimal design as proposed by Shin in [126], who in a first stage uses the algorithm K-clustering algorithm to create k-groups of wind turbines within the internal grid; these, in turn, are interconnected according to different parameters such as the distance to a random center or the radial angle between the turbine and the substation. Once the groups are obtained, the MST (minimum spanning tree algorithm) is used to connect one turbine to another by the shortest path, and in the last step, a local search optimization algorithm is used to obtain the optimal point to connect to the outer grid, to minimizing the cable section [127].

The research focused on the connection to grid for wind farms can be understood to have begun in 2002, this topic being studied with great scientific production until 2012; since then, scientific interest has greatly decreased. The countries by order of importance of scientific output are China, the United Kingdom, Germany, Spain, Denmark, and the United States. All these countries have strong investments in this technology or are in need of locating wind farms. Regarding the institutions with high productivity in this field, the first and second belong to China (North China Electric Power University and China Electric Power Research Institute), and the third to the UK (University of Strathclyde). As for the main keywords, they are offshore wind farms, HVDC power transmission, and asynchronous generators. Focusing on offshore wind farms, the most important works are those related to HVDC connection to the transmission system [128] and its relationship with doubly fed induction generators [129], control and design of DC grids [130], and the prospect for cost reduction [131].

\section{Wind Generator Modeling}

Analyzing scientific production on wind generator modeling as per the Scopus Database, we can find 3700 documents on this topic. The strong research on modeling for wind generators began in 2000, with more than 10 publications on this issue, reaching a maximum of 443 documents in 2014. This scientific output is distributed equally between articles and conference papers, which demonstrates a great activity of scientific meetings in this field. The countries which led this research were China, the 
United States, India, the United Kingdom, and Canada. Among the attending institutions or affiliations, the top 10 were: IEEE (USA), North China Electric Power University (China), Tsinghua University (China), Danmarks Tekniske Universitet (Denmark), Aalborg Universitet (Denmark), China Electric Power Research Institute (China), University of Strathclyde (UK), Delft University of Technology (Netherlands), University of Manchester (UK), and National Renewable Energy Laboratory (USA).

If the keywords of all these works are analyzed, it is possible to observe that there are some subjects with more relative relevance: asynchronous generators and synchronous generators, electric generators and electric utilities or electric power transmission networks. The most cited keywords are shown in Table 3. It is worth noting that there is a much higher frequency for the keyword asynchronous generators than for permanent magnet synchronous generator (PMSG), although the most interesting and most installed is PMSG.

Table 3. Keywords and their frequency in wind turbine modeling.

\begin{tabular}{|c|c|}
\hline Keyword & Frequency \\
\hline Wind Power & 2039 \\
\hline Wind Turbines & 1503 \\
\hline Asynchronous Generators & 827 \\
\hline Electric Generators & 777 \\
\hline Computer Simulation & 584 \\
\hline Electric Utilities & 582 \\
\hline Electric Power Transmission Networks & 444 \\
\hline Synchronous Generators & 444 \\
\hline Wind Turbine & 427 \\
\hline Electric Fault Currents & 395 \\
\hline Electric Power Generation & 336 \\
\hline Permanent Magnets & 331 \\
\hline Turbines & 303 \\
\hline Modeling & 302 \\
\hline Energy Conversion & 286 \\
\hline Mathematical Models & 275 \\
\hline Wind & 270 \\
\hline Wind Energy & 270 \\
\hline Wind Farm & 268 \\
\hline Renewable Energy Resources & 265 \\
\hline Permanent Magnet Synchronous Generator & 245 \\
\hline Turbogenerators & 234 \\
\hline Doubly Fed Induction Generators & 233 \\
\hline MATLAB & 231 \\
\hline Doubly Fed Induction Generator (DFIG) & 221 \\
\hline Electric Power Systems & 220 \\
\hline Power Converters & 216 \\
\hline Controllers & 203 \\
\hline Optimization & 203 \\
\hline Wind Speed & 196 \\
\hline
\end{tabular}

When modeling a wind farm, there are thousands of modeling parameters. It is not enough to model the output power of a turbine that depends on the density of the air, the area swept by the blades, and the wind speed. Given the level of complexity and size that new farms are acquiring, various models can be found for the main components. According to the literature, two classifications can be established: modeling the wind turbine and modeling the wind farm. Some authors focus on standalone facilities to model the constructive and structural parameters of the wind turbine, where they focus their study on parameters such as the blades, reducer, motor, electronics or structure. Others, meanwhile, focus on larger models, where location, layout, interconnection or hybridization are of great importance, although the final objective must clearly maximize the performance of the installation and minimize the cost of it. 
Some authors simplify the turbine model by eliminating any active electronics in order to construct a low-cost model in order to evaluate the constructive and structural parameters of the installation. Maalawi in 2002 presented a model for the design of blades where parameters such as the cross-sectional area, the turning radius, and the length of each segment are considered in order to obtain the maximum frequency [132], while other authors tried to optimize blade modeling, basing their approach on parameters such as vibrations, torsion, and size while minimizing the cost of energy production for both losses and rotor cost [133]. Li et al. [134] performed a comparative study between the reduction ratio of the reducer and the output power, minimizing the cost of the generator; in this study, different technologies are compared-direct-drive generators with hybrid systems of different stages of reduction.

Advancing towards more complex solutions, some authors seek the distribution of the wind farm based on the optimal distribution of wind turbines in order to maximize production. Many authors propose a multiobjective evolutionary algorithm (MOEA) to find the optimal layout. According to this method, in an initial stage, the type of turbine is selected from a set whose yields are known. More complex methods allow the selection of different types of turbines generating hybrid models. Once the wind turbines have been selected, a random distribution is performed within the surface of the wind farm, which will be evaluated according to an objective function, with model parameters such as wind direction, turbine interaction distribution, or feasibility of implementation [119].

\section{Wind Generator Control}

At present, there are different techniques of wind generator control (see Figure 14) so that a wind turbine is normally designed to work within specific wind speeds, with it being necessary to limit the power output or the speed of the wind turbine above the nominal value established [134-136].

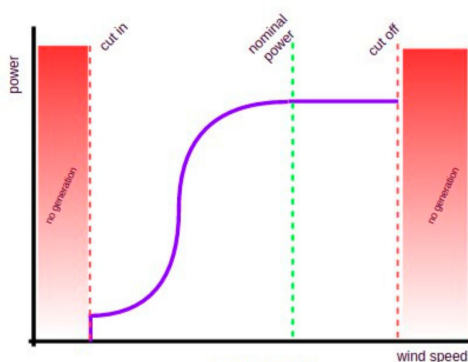

Pitch Control

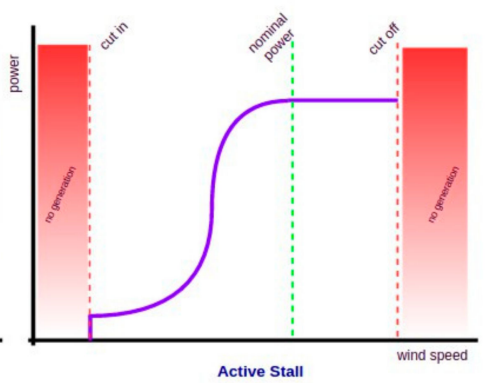

Active Stall

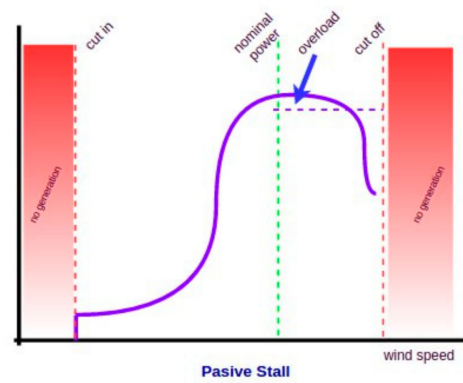

Pasive Stall

Figure 14. Different techniques of wind turbines control.

The following classifications can be made:

Passive Stall Controlled. In this case, the blades of the wind turbine are bolted to it at a certain angle (blade pitch) depending on the design speed. The geometry of the blade has been designed so that when high wind speeds are reached, a turbulence in the wind turbine will be generated, causing the wind turbine to brake and stop. Given its simplicity, it is one of the most implemented methods in wind turbines. Its main problem is that it does not respond well to wind gusts, causing in most cases an undesirable overpowering of the system.

Active Stall Controlled. This system includes a mechanism that allows varying the inclination of the blades of the wind turbine; thus, when an unwanted wind speed is reached, the blades rotate in the opposite direction, causing a resistance and reducing the rotation speed of the rotor or even stopping it. It also allows us to achieve the opposite effect, allowing the positioning of the blades in a beneficial position to start at low wind speeds. Normally, a series of jumps are designed where it is possible to position the blades to obtain the desired effect. It is a method widely used in turbines over 1 MW.

Pitch Control: This method provides a greater control of tilting positioning of the blades, since the generator output power is used to control the tilting angle of the blades, i.e., the output power is used as feedback, giving a greater or lesser angle of inclination to the blades. In this way, when the 
wind speed increases, the control algorithm sees how the output power increases and orders a new tilting position of the blades, until the blade tilting position is optimized for the current wind speed.

The difference between the active stall control and the pitch control is that while the active stall control is based on generating the turbulence to obtain the resistance and to make the rotor stop, the pitch control is based on the idea of positioning the blade to reduce the force on the blades and get the stop. This technique requires a sophisticated control algorithm and drives, usually hydraulic or motor reducer (the latter more usual due to their lower maintenance), which increase the complexity in the design of the rotor. Usually, they are implemented in large turbines over $4 \mathrm{MW}$.

However, if the study focuses on the wind generation zone, different control techniques can be found. Mainly two classifications can be made:

Fixed Speed. Within this group are two types mainly, although the principle is the same: one speed or two speeds. In the first case, the system is designed so that the generator works at full power at a certain speed. Working at two speeds can be achieved either depending on the wind by changing the number of poles of the motor or by installing two generators in tandem and connecting one or the other to the grid depending on the optimal speed. Within this group, any of the strategies of the control of blades previously seen are used, but that does not happen in the same way in those of variable speed, where a pitch control is almost certainly applied.

Variable Speed. Mainly two groups are distinguished, depending on whether a reducer, direct-drive or gearbox is used or not, with direct-drive being more and more commonly found as the solution. However, at power electronics level, you can find a multitude of strategies in both cases. The trend leads us to the permanent magnet synchronous generator (PMSG) and the WRSG wound rotor synchronous generator, both strategies based on synchronous machines. In the first one, the output power proportional to the input torque is obtained; it is the system controller which, when playing with the tilt control, can effectively control the output power of the system and the efficient connection with the grid in function of the needs, being an efficient solution. While with the WRSG solution the field excitation can be controlled to adjust the load.

\section{Conclusions}

The construction of foundations for the offshore wind turbine industry still faces many technical challenges that should be solved on a case-by-case basis. At present, there are several types of structures that have allowed for an early development of the offshore wind turbine industry, but there is still a long way to optimization. Floating structures are neither a technically nor economically viable solution yet. Larger wind turbines will help towards serial production of this kind of technologies, but transportation and installation costs must be lower. Regarding jacket leg foundations, the main problem during manufacturing remains the high number of weldings needed to attach together individual pieces, which could lead to structural problems increasing the OPEX costs as well as the CAPEX in the long term, during the life of the project, due to the complexity of these weldings demanding many hours of very specialized welders and high-cost steel plates. On the other hand, the main problem with jacket leg foundations during the installation phase is to do with the need for usage of heavy lift vessel for lifting operations due to size issues. The market availability of this kind of vessels, which come with very limited installation windows and are subject to weather downtime, leads to high cost. The usage of most spread-out, fixed-foundation, monopile structures seem to be coming close to an end when it comes to deeper water projects. Nevertheless, big offshore developer companies are investigating alternatives for using massive monopiles structures (bigger diameter, more tonnage, and thicker edge) in deeper waters, far from currently near-shore projects due to the cost-effectiveness of this sort of structures compared to jacket leg foundations, not only because of manufacturing simplicity but also due to the easy access to installation vessels. In summary, the connections between wind turbines and substations together with the foundations must be considered jointly in order to reach the maximum between electrical performance and minimum costs in offshore wind farm facilities. 
Regarding the techniques of wind turbine control based on wind speeds, in short, passive stall control is one of the most implemented methods in wind turbines due its simplicity. Its main problem is that it does not respond well to wind gusts, causing in most cases an undesirable overpowering of the system. On the other hand, the active stall control and the pitch regulate in inclination, but the main difference between the two is that one does so to generate turbulence (active stall control) and the other to place the blades in a position so that the wind does not turn them, which is more beneficial for the mechanic. If the wind generator control is based on the wind generation zone, we can first find the fixed speed mainly with two types: one speed or two speeds. Both systems are designed so that the generator works at full power at a certain speed. Secondly, we can find a variable speed, where the trend leads us to use strategies based on synchronous machines: the permanent magnet synchronous generator (PMSG) and the wound rotor synchronous generator (WRSG).

Author Contributions: M.S.-C. and F.M.-A. conceived the manuscript; A.-J.P.-M., C.S.-A.-G., and M.S.C. performed the figures; A.-J.P.-M., C.S.-A.-G., F.M.-A., and M.S.-C. performed the experiments and analyzed the data; A.-J.P.-M., F.M.-A., A.A., and M.S.-C. wrote the paper. E.S.-M. and C.S.-A.-G. revised the whole manuscript and contributed with the revision of the manuscript. All authors have read and agreed to the published version of the manuscript.

Conflicts of Interest: The authors declare no conflict of interest.

\section{References}

1. Oh, K.Y.; Nam, W.; Ryu, M.S.; Kim, J.Y.; Epureanu, B.I. A review of foundations of offshore wind energy convertors: Current status and future perspectives. Renew. Sustain. Energy Rev. 2018, 88, 16-36. [CrossRef]

2. Shehzad, M.F.; Abdelghany, M.B.; Liuzza, D.; Mariani, V.; Glielmo, L. Mixed Logic Dynamic Models for MPC Control of Wind Farm Hydrogen-Based Storage Systems. Inventions 2019, 4, 57. [CrossRef]

3. Hernández-Escobedo, Q.; Saldaña-Flores, R.; Rodríguez-García, E.R.; Manzano-Agugliaro, F. Wind energy resource in Northern Mexico. Renew. Sustain. Energ. Rev. 2014, 32, 890-914. [CrossRef]

4. Chakrabarti, S. Handbook of Offshore Engineering (2-volume set); Elsevier: Amsterdam, The Nederlands, 2005.

5. Colmenar-Santos, A.; Perera-Perez, J.; Borge-Diez, D.; Depalacio-Rodríguez, C. Offshore wind energy: A review of the current status, challenges and future development in Spain. Renew. Sustain. Energ. Rev. 2016, 64, 1-18. [CrossRef]

6. Mazidi, P.; Tohidi, Y.; Sanz-Bobi, M.A. Strategic Maintenance Scheduling of an Offshore Wind Farm in a Deregulated Power System. Energies 2017, 10, 313. [CrossRef]

7. Nernheim, A.; Vasquez, A.; Wilke, F.; Kahle, H. Geotechnical site specific assessment for offshore-wind jackup vessels. GEOTECHNIK 2015, 38, 3-16. [CrossRef]

8. Sumer, B.M. Flow-structure-seabed interactions in coastal and marine environments. J. Hydraul. Res. 2014, 52, 1-13. [CrossRef]

9. International Energy Agency. Global Wind Statistics 2019. Available online: https://www.iea.org/reports/ offshore-wind-outlook-2019 (accessed on 12 January 2020).

10. Gjersøe, N.F.; Pedersen, E.B.; Kristiansen, B.; Hansen, N.O.; Ibsen, L.B. Weight optimisation of steel monopile foundations for offshore windfarms. In Proceedings of the International Offshore and Polar Engineering Conference, Kona, HI, USA, 21-26 June 2015; pp. 245-252.

11. Prakhya, G.; Zhang, C.; Harding, N. Grouted connections for monopiles-limits for large wind turbines. Struct. Eng. 2012, 90, 30-45.

12. Seidel, M. Design, fabrication and installation of the offshore wind turbine REpower 5M. [Tragstruktur und Installation der Offshore-Windenergieanlage REpower 5M]. STAHLBAU 2007, 76, 650-656. [CrossRef]

13. Pliego Marugán, A.; García Márquez, F.P.; Pinar Pérez, J.M. Optimal Maintenance Management of Offshore Wind Farms. Energies 2016, 9, 46. [CrossRef]

14. Vis, I.F.A.; Ursavas, E. Assessment approaches to logistics for offshore wind energy installation. Sustain. Energy Technol. Assess. 2016, 14, 80-91. [CrossRef]

15. Zhang, P.; Zhang, Z.; Liu, Y.; Ding, H. Experimental study on installation of composite bucket foundations for offshore wind turbines in silty sand. J. Offshore Mech. Arct. Eng. 2016, 138, 061901. [CrossRef] 
16. Manzano-Agugliaro, F.; Sanchez-Calero, M.; Perea-Moreno, A.J.; San-Antonio-Gomez, C. Ensayo de segregación en cimentaciones para la estructura soporte de aerogeneradores off-shore hechas por vertido en caída libre. DYNA 2018, 93, 221-227. [CrossRef]

17. Arany, L.; Bhattacharya, S.; Macdonald, J.H.G.; Hogan, S.J. Closed form solution of eigen frequency of monopile supported offshore wind turbines in deeper waters incorporating stiffness of substructure and SSI. Soil Dyn. Earthq. Eng. 2016, 83, 18-32. [CrossRef]

18. Bakhoday-Paskyabi, M.; Fer, I.; Reuder, J. Current and turbulence measurements at the FINO1 offshore wind energy site: Analysis using 5-beam ADCPs. Ocean Dyn. 2018, 68, 109-130. [CrossRef]

19. Lind, P.; Vera-Tudela, L.; Wächter, M.; Kühn, M.; Peinke, J. Normal behaviour models for wind turbine vibrations: Comparison of neural networks and a stochastic approach. Energies 2017, 10, 1944. [CrossRef]

20. Esteban, M.D.; Couñago, B.; López-Gutiérrez, J.S.; Negro, V.; Vellisco, F. Gravity based support structures for offshore wind turbine generators: Review of the installation process. Ocean Eng. 2015, 110, 281-291. [CrossRef]

21. O'Kelly, B.C.; Arshad, M. Offshore wind turbine Foundations-Analysis and design. In Offshore Wind Farms: Technologies, Design and Operation; Woodhead Publishing: Oxford, UK, 2016; pp. 589-610. [CrossRef]

22. Sánchez, S.; López-Gutiérrez, J.S.; Negro, V.; Esteban, M.D. Foundations in Offshore Wind Farms: Evolution, Characteristics and Range of Use. Analysis of Main Dimensional Parameters in Monopile Foundations. J. Mar. Sci. Eng. 2019, 7, 441. [CrossRef]

23. Esteban, M.D.; López-Gutiérrez, J.S.; Negro, V.; Sanz, L. Riprap Scour Protection for Monopiles in Offshore Wind Farms. J. Mar. Sci. Eng. 2019, 7, 440. [CrossRef]

24. Lesny, K.; Wiemann, J. Design aspects of monopiles in German offshore wind farms. In Proceedings of the International Symposium on Frontiers in Offshore Geotechnics, London, UK, 19-21 September 2005; pp. 383-389.

25. Shadlou, M.; Bhattacharya, S. Dynamic stiffness of monopiles supporting offshore wind turbine generators. Soil Dyn. Earthq. Eng. 2016, 88, 15-32. [CrossRef]

26. Dahlhaus, F.; Großmann, J. Design and installation of an innovative tension leg platform for 2 MW offshore wind turbine at baltic sea. In Proceedings of the Paper presented at the Offshore Technology Conference 2016, Houston, TX, USA, 2-5 May 2016; pp. 2441-2447. [CrossRef]

27. Negro, V.; López-Gutiérrez, J.; Esteban, M.D.; Matutano, C. Uncertainties in the design of support structures and foundations for offshore wind turbines. Renew. Energy 2014, 63, 125-132. [CrossRef]

28. Rüdiger, S. Steel Engineering and Construction, 2013. Available online: https://www.max-boegl.de/dk/ downloads-dk/806-steel-engineering-and-construction-2/file.html (accessed on 16 December 2019).

29. Kallehave, D.; Byrne, B.W.; LeBlanc Thilsted, C.; Mikkelsen, K.K. Optimization of monopiles for offshore wind turbines. Philos. Trans. R. Soc. A Math. Phys. Eng. Sci. 2015, 373, 20140100. [CrossRef] [PubMed]

30. Arany, L.; Bhattacharya, S.; MacDonald, J.H.G.; Hogan, S.J. A critical review of serviceability limit state requirements for monopile foundations of offshore wind turbines. In Proceedings of the Annual Offshore Technology Conference, Houston, TX, USA, 4-7 May 2015; Volume 4, pp. 2570-2587.

31. Scharff, R.; Siems, M. Monopile foundations for offshore wind turbines-solutions for greater water depths. Steel Constr. 2013, 6, 47-53. [CrossRef]

32. Fraenkel, P. The tide turns for marine current turbines. Int. Water Power Dam Constr. 2001, 53, 18-21.

33. Bhattacharya, S.; Adhikari, S. Experimental validation of soil-structure interaction of offshore wind turbines. Soil Dyn. Earthq. Eng. 2011, 31, 805-816. [CrossRef]

34. Bisoi, S.; Haldar, S. Dynamic analysis of offshore wind turbine in clay considering soil-monopile-tower interaction. Soil Dyn. Earthq. Eng. 2014, 63, 19-35. [CrossRef]

35. Damgaard, M.; Ibsen, L.B.; Andersen, L.V.; Andersen, J.K. Cross-wind modal properties of offshore wind turbines identified by full scale testing. J. Wind Eng. Ind. Aerodyn. 2013, 116, 94-108. [CrossRef]

36. Lackner, M.A.; Rotea, M.A. Passive structural control of offshore wind turbines. Wind Energy 2011, 14, 373-388. [CrossRef]

37. Dvorak, M.J.; Archer, C.L.; Jacobson, M.Z. California offshore wind energy potential. Renew. Energy 2010, 35, 1244-1254. [CrossRef]

38. Chiang, Y.; Lee, P.; Chen, P.; Lin, S.; Hsiao, S. A study on low-cost gravity base foundations for offshore wind turbine in Taiwan. In Proceedings of the International Offshore and Polar Engineering Conference, Kona, HI, USA, 21-26 June 2015; pp. 289-296. 
39. Whitehouse, R.J.S.; Sutherland, J.; Harris, J.M. Evaluating scour at marine gravity foundations. In Proceedings of the Institution of Civil Engineers: Maritime Engineering; Thomas Telford Ltd.: London, UK, 2011; Volume 164, pp. 143-157. Available online: https://www.icevirtuallibrary.com/doi/full/10.1680/maen.2011.164.4.143 (accessed on 21 December 2019).

40. Landbø, T.; Wiley, N.M.; Godejord, A.; Sveen, D. Wind technology moves into deeper water. In Proceedings of the 16th Offshore Symposium-Energy from the Oceans, Houston, TX, USA, 9 February 2010; pp. A13-A23.

41. Chiang, Y.; Lee, P.; Chen, C. A study on the mooring system for the sinking installation of the preassembling offshore wind turbine. In Proceedings of the International Offshore and Polar Engineering Conference, Rhodes, Greece, 26 June-2 July 2016; pp. 151-155.

42. He, R.; Wang, L. Elastic rocking vibration of an offshore gravity base foundation. Appl. Ocean Res. 2016, 55, 48-58. [CrossRef]

43. Zachert, H.; Wichtmann, T.; Triantafyllidis, T.; Hartwig, U. Simulation of a full-scale test on a gravity base foundation for offshore wind turbines using a high cycle accumulation model. In Proceedings of the Frontiers in Offshore Geotechnics III-3rd International Symposium on Frontiers in Offshore Geotechnics, Leiden, The Netherlands; Meyer, Ed.; Taylor \& Francis Group: London, UK, 2015; pp. 819-824. ISBN 978-1-138-02848-7.

44. Winkler, M.; Ole Stromme, S. Development Drilling and Production Platforms, 2014 . Available online: http://www.npcarcticpotentialreport.org/pdf/tp/6-5_Development_Drilling_and_Production_ Platforms.pdf (accessed on 16 December 2019).

45. Van Poppel, R. In-shop to offshore: Shop coating steel for the thornton bank wind farm. J. Prot. Coat. Linings 2014, 31, 52-57.

46. Zhu, B.; Byrne, B.W.; Houlsby, G.T. Long-term lateral cyclic response of suction caisson foundations in sand. J. Geotech. Geoenvironmental Eng. 2012, 139, 73-83. [CrossRef]

47. Dixon, J.C.; Swift, R.H. Structure design for compliant tower offshore wind turbines. In Proceedings of the 4th BWEA Conference, Cranfield, UK, 24-26 March 1982; pp. 299-306.

48. Harte, M.; Basu, B.; Nielsen, S.R. Dynamic analysis of wind turbines including soil-structure interaction. Eng. Struct. 2012, 45, 509-518. [CrossRef]

49. Harris, J.M.; Whitehouse, R.J.; Sutherland, J. Marine Scour and Offshore Wind: Lessons Learnt and Future Challenges. In Proceedings of the ASME 2011 30th International Conference on Ocean, Offshore and Arctic Engineering, Rotterdam, The Netherlands, 19-24 June 2011; pp. 849-858.

50. Plodpradit, P.; Dinh, V.N.; Kim, K.D. Coupled analysis of offshore wind turbine jacket structures with pile-soil-structure interaction using FAST v8 and X-SEA. Appl. Sci. 2019, 9, 1633. [CrossRef]

51. Carbon Trust (2020). Available online: www.carbontrust.com (accessed on 11 January 2020).

52. Crampsie, S. Firm foundations. Eng. Technol. 2014, 9, 64-67. [CrossRef]

53. Betke, K. Underwater construction and operational noise at alpha ventus. In Ecological Research at the Offshore Windfarm Alpha Ventus: Challenges, Results and Perspectives; Springer Spektrum: Wiesbaden, Germany, 2014; pp. 171-180. [CrossRef]

54. Seidel, M.; Foss, G. Impact of different substructures on turbine loading and dynamic behaviour for the DOWNVInD Project in $45 \mathrm{~m}$ water depth. In Proceedings of the Conference Proceedings EWEC 2006, Athens, Greece, 27 February-2 March 2006; Available online: https://pdfs.semanticscholar.org/48eb/98c5f5833238ba4d2b0e493e006df3a47269.pdf?_ga=2.202964371. 343505474.1579545842-1304111355.1579545842 (accessed on 20 December 2019).

55. 4C Offshore. 4C Offshore, 2015. Available online: http://www.4coffshore.com/windfarms/siemens-passeson-sylwin1-nid1701.html (accessed on 20 December 2019).

56. Shi, W.; Park, H.; Chung, C.; Baek, J.; Kim, Y.; Kim, C. Load analysis and comparison of different jacket foundations. Renew. Energy 2013, 54, 201-210. [CrossRef]

57. Zhang, J.; Gao, D.; Sun, K.; Zhang, Z. Ship impact behavior on jacket type offshore wind turbine foundation. In Proceedings of the International Conference on Offshore Mechanics and Arctic Engineering-OMAE, San Francisco, CA, USA, 8-13 June 2014; Volume 4B. [CrossRef] 
58. Alati, N.; Arena, F.; Failla, G.; Nava, V. Fatigue analysis of tripods and jackets for offshore wind turbines. In Proceedings of the Sustainable Maritime Transportation and Exploitation of Sea Resources-14th International Congress of the International Maritime Association of the Mediterranean, Shanghai, China, In Proceedings of the Sustainable Maritime Transportation and Exploitation of Sea Resources-14th International Congress of the International Maritime Association of the Mediterranean, Genova, Italy, 13-16 September 2011; Volume 2, pp. 1099-1106.

59. Chen, D.; Huang, K.; Bretel, V.; Hou, L. Comparison of structural properties between monopile and tripod offshore wind-turbine support structures. Adv. Mech. Eng. 2013, 5, 175684. [CrossRef]

60. Offshore Wind Industry (2020). Available online: http://www.offshorewindindustry.com (accessed on 10 January 2020).

61. Resterhellweg, A.; Cañadillas, B.; Kinder, F.; Neumann, T. Wake measurements at alpha ventus-Dependency on stability and turbulence intensity. J. Phys. Conf. Ser. 2014, 555, 012106. [CrossRef]

62. Junginger, M.; Faaij, A.; Turkenburg, W.C. Cost reduction prospects for offshore wind farms. Wind Eng. 2004, 28(1), 97-118. [CrossRef]

63. Von Wedel, H. Vessel design criteria for valuable assets in the logistical chain of offshore wind park erection and maintenance. In Proceedings of the RINA; Royal Institution of Naval Architects-Marine Renewable and Offshore Wind Energy: London, UK, 2010; pp. 165-169.

64. Kirsch, F.; Klingmüller, O. Driving of foundation piles for offshore wind turbines. In Proceedings of the Geotechnical Special Publication, Oakland, CA, USA, 20 June 2012; pp. 471-482. [CrossRef]

65. Goseberg, N.; Franz, B.; Schlurmann, T. The potential co-use of aquaculture and offshore wind energy structures. In Proceedings of the 6th Chinese-German Joint Symposium on Hydraulic and Ocean Engineering, CGJOINT, Keelung, Taiwan, 23-29 September 2012; pp. 597-603.

66. Jose, N.M.; Mathai, A. A Study on Lateral Deformation of Monopile of Offshore Wind Turbine due to Environmental Loads. Procedia Technol. 2016, 24, 287-294. [CrossRef]

67. Koulin, G.; Sewell, I.; Shaw, B.A. Faceted monopile design suitable for mass production and upscaling. Procedia Eng. 2015, 114, 385-392. [CrossRef]

68. Zaaijer, M.B. Comparison of monopile, tripod, suction bucket and gravity base design for a $6 \mathrm{MW}$ turbine. In Proceedings of the Offshore Wind Energy in Mediterranean and Other European Seas: Resources, Technology, Applications: OWEMES 2003, Naples - Campania, Italy, 10-12 April 2003; pp. 1-15. Available online: https: //pdfs.semanticscholar.org/58ef/771f0c2c6665a4189226ba55ead09a8aaa18.pdf (accessed on 20 December 2019).

69. Achmus, M.; Akdag, C.T.; Thieken, K. Load-bearing behavior of suction bucket foundations in sand. Appl. Ocean Res. 2013, 43, 157-165. [CrossRef]

70. Urban, S.; Strauss, A.; Reiterer, M.; Wagner, R. Experimental modeling of fatigue processes to detect the real degree of deterioration. In Proceedings of the Life-Cycle and Sustainability of Civil Infrastructure Systems-3rd International Symposium on Life-Cycle Civil Engineering, Vienna, Austria, 3-6 October 2012; pp. $1438-1446$.

71. Safinus, S.; Sedlacek, G.; Hartwig, U. Analysis of gravity base foundation for offshore wind turbine under cyclic loads. In Proceedings of the Twenty-First International Offshore and Polar Engineering Conference, Maui, HI, USA, 19-24 June 2011.

72. Wang, H.F.; Fan, Y.H.; Moreno, I. Analysis of a preliminary configuration for a floating wind turbine. Struct. Eng. Mech. 2016, 59, 559-577. [CrossRef]

73. Lamas-Pardo, M.; Iglesias, G.; Carral, L. A review of Very Large Floating Structures (VLFS) for coastal and offshore uses. Ocean Eng. 2015, 109, 677-690. [CrossRef]

74. Kandasamy, R.; Cui, F.; Townsend, N.; Foo, C.C.; Guo, J.; Shenoi, A.; Xiong, Y. A review of vibration control methods for marine offshore structures. Ocean Eng. 2016, 127, 279-297. [CrossRef]

75. Rodrigues, S.; Restrepo, C.; Kontos, E.; Pinto, R.T.; Bauer, P. Trends of offshore wind projects. Renew. Sustain. Energ. Rev. 2015, 49, 1114-1135. [CrossRef]

76. Mohamed, A.; Ibrahim, Z.Z.; Silong, A.D.; Abdullah, R. Distributed Leadership in a Low-Carbon City Agenda. Sustainability 2016, 8, 715. [CrossRef]

77. Song, J.; Lim, H.C. Study of Floating Wind Turbine with Modified Tension Leg Platform Placed in Regular Waves. Energies 2019, 12, 703. [CrossRef]

78. Salic, T.; Charpentier, J.F.; Benbouzid, M.; Le Boulluec, M. Control Strategies for Floating Offshore Wind Turbine: Challenges and Trends. Electronics 2019, 8, 1185. [CrossRef] 
79. Koh, J.H.; Ng, E.Y.K. Downwind offshore wind turbines: Opportunities, trends and technical challenges. Renew. Sustain. Energ. Rev. 2016, 54,797-808. [CrossRef]

80. Rodrigues, S.F.; Pinto, R.T.; Soleimanzadeh, M.; Bosman, P.A.; Bauer, P. Wake losses optimization of offshore wind farms with moveable floating wind turbines. Energy Conv. Manag. 2015, 89, 933-941. [CrossRef]

81. Du, W.; Zhao, Y.; He, Y.; Liu, Y. Design, analysis and test of a model turbine blade for a wave basin test of floating wind turbines. Renew. Energy 2016, 97, 414-421. [CrossRef]

82. Bauer, D. Design, Fabrication and Installation Implications for Offshore Wind Turbine Support Structures; Royal Aeronautical Society: London, UK, 1988; pp. 6.1-6.25.

83. Roddier, D.; Cermelli, C.; Aubault, A.; Weinstein, A. WindFloat: A floating foundation for offshore wind turbines. J. Renew. Sustain. Energy 2010, 2, 033104. [CrossRef]

84. Sebastian, T.; Lackner, M.A. Development of a free vortex wake method code for offshore floating wind turbines. Renew. Energy 2012, 46, 269-275. [CrossRef]

85. Sethuraman, L.; Venugopal, V. Hydrodynamic response of a stepped-spar floating wind turbine: Numerical modelling and tank testing. Renew. Energy 2013, 52, 160-174. [CrossRef]

86. Jeon, S.H.; Cho, Y.U.; Seo, M.W.; Cho, J.R.; Jeong, W.B. Dynamic response of floating substructure of spar-type offshore wind turbine with catenary mooring cables. Ocean Eng. 2013, 72, 356-364. [CrossRef]

87. Namik, H.; Stol, K. Individual blade pitch control of floating offshore wind turbines. Wind Energy 2010, 13, 74-85. [CrossRef]

88. Liu, Y.; Li, S.; Yi, Q.; Chen, D. Developments in semi-submersible floating foundations supporting wind turbines: A comprehensive review. Renew. Sustain. Energ. Rev. 2016, 60, 433-449. [CrossRef]

89. Wang, K.; Moan, T.; Hansen, M.O. Stochastic dynamic response analysis of a floating vertical-axis wind turbine with a semi-submersible floater. Wind Energy 2016, 19(10), 1853-1870. [CrossRef]

90. Antonutti, R.; Peyrard, C.; Johanning, L.; Incecik, A.; Ingram, D. The effects of wind-induced inclination on the dynamics of semi-submersible floating wind turbines in the time domain. Renew. Energy 2016, 88, 83-94. [CrossRef]

91. Karimirad, M.; Michailides, C. V-shaped semisubmersible offshore wind turbine: An alternative concept for offshore wind technology. Renew. Energy 2015, 83, 126-143. [CrossRef]

92. Roddier, D.; Cermelli, C.; Weinstein, A. WindFloat: A floating foundation for offshore wind turbines-Part I: Design basis and qualification process. In Proceedings of the ASME 2009 28th International Conference on Ocean, Offshore and Arctic Engineering, Honolulu, HI, USA, 31 May-5 June 2009; pp. 845-853.

93. Valverde, P. The WindFloat Project-WindFloat 2 MW floating offshore wind. In Proceedings of the 10th Deep Sea Offshore Wind R\&D Conference, Trondheim, Norway, 24-25 January 2013.

94. Hall, M.; Goupee, A. Validation of a lumped-mass mooring line model with DeepCwind semisubmersible model test data. Ocean Eng. 2015, 104, 590-603. [CrossRef]

95. Cheng, Z.; Madsen, H.A.; Gao, Z.; Moan, T. Effect of the number of blades on the dynamics of floating straight-bladed vertical axis wind turbines. Renewable Energy 2017, 101, 1285-1298. [CrossRef]

96. Bayati, I.; Jonkman, J.; Robertson, A.; Platt, A. The effects of second-order hydrodynamics on a semisubmersible floating offshore wind turbine. J. Phys. Conf. Ser. 2014, 524, 012094. [CrossRef]

97. Muliawan, M.J.; Karimirad, M.; Moan, T. Dynamic response and power performance of a combined spar-type floating wind turbine and coaxial floating wave energy converter. Renew. Energy 2013, 50, 47-57. [CrossRef]

98. Karimirad, M.; Moan, T. Wave-and wind-induced dynamic response of a spar-type offshore wind turbine. J. Waterw. Port Coast. Ocean Eng. 2011, 138, 9-20. [CrossRef]

99. Karimirad, M.; Meissonnier, Q.; Gao, Z.; Moan, T. Hydroelastic code-to-code comparison for a tension leg spar-type floating wind turbine. Mar. Struct. 2011, 24, 412-435. [CrossRef]

100. Cheng, Z.; Wang, K.; Gao, Z.; Moan, T. A comparative study on dynamic responses of spar-type floating horizontal and vertical axis wind turbines. Wind Energy 2017, 20, 305-323. [CrossRef]

101. Gutiérrez-Romero, J.E.; García-Espinosa, J.; Serván-Camas, B.; Zamora-Parra, B. Non-linear dynamic analysis of the response of moored floating structures. Marine Structures 2016, 49, 116-137.

102. Muliawan, M.J.; Karimirad, M.; Moan, T.; Gao, Z. STC (Spar-Torus Combination): A combined spar-type floating wind turbine and large point absorber floating wave energy converter-Promising and challenging. In Proceedings of the ASME 2012 31st International Conference on Ocean, Offshore and Arctic Engineering, Rio de Janeiro, Brazil, 1-6 July 2012; pp. 667-676.

103. Stiesdal, H. Hywind: The world's first floating MW-scale wind turbine. Wind Dir. 2009, 31, 52-53. 
104. Karimirad, M.; Moan, T. Extreme dynamic structural response analysis of catenary moored spar wind turbine in harsh environmental conditions. J. Offshore Mech. Arct. Eng. 2011, 133, 041103. [CrossRef]

105. Xing, Y.; Karimirad, M.; Moan, T. Modelling and analysis of floating spar-type wind turbine drivetrain. Wind Energy 2014, 17, 565-587. [CrossRef]

106. Arias, R.R.; Ruiz, Á.R.; De Lena Alonso, V.G. Mooring and Anchoring. In Floating Offshore Wind Farms; Springer International Publishing: Berlin/Heidelberg, Germany, 2016; pp. 89-119.

107. Lin, Y.H.; Kao, S.H.; Yang, C.H. Investigation of Hydrodynamic Forces for Floating Offshore Wind Turbines on Spar Buoys and Tension Leg Platforms with the Mooring Systems in Waves. Appl. Sci. 2019, 9, 608. [CrossRef]

108. Moon, W.L., III; Nordstrom, C.J. Tension leg platform turbine: A unique integration of mature technologies. In Proceedings of the 16th Offshore Symposium, Texas Section of the Society of Naval Architects and Marine Engineers, Houston, TX, USA, 9 February 2010; pp. A25-A34.

109. Jonkman, J.M.; Matha, D. Dynamics of offshore floating wind turbines-Analysis of three concepts. Wind Energy 2011, 14, 557-569. [CrossRef]

110. Ren, N.; Li, Y.; Ou, J. The effect of additional mooring chains on the motion performance of a floating wind turbine with a tension leg platform. Energies 2012, 5, 1135-1149. [CrossRef]

111. Shen, M.; Hu, Z.; Liu, G. Dynamic response and viscous effect analysis of a TLP-type floating wind turbine using a coupled aero-hydro-mooring dynamic code. Renew. Energy 2016, 99, 800-812. [CrossRef]

112. Vita, L.; Ramachandran, G.K.V.; Krieger, A.; Kvittem, M.I.; Merino, D.; Cross-Whiter, J.; Ackers, B.B. Comparison of Numerical Models and Verification Against Experimental Data, Using Pelastar TLP Concept. In Proceedings of the ASME 2015 34th International Conference on Ocean, Offshore and Arctic Engineering, St. John's, NL, Canada, 31 May-5 June 2015; p. V009T09A047.

113. Bouzounierakis, N.; Katsigiannis, Y.; Fiorentzis, K.; Karapidakis, E. Effect of Hybrid Power Station Installation in the Operation of Insular Power Systems. Inventions 2019, 4, 38. [CrossRef]

114. Nandigam, M.; Dhali, S.K. Optimal design of an offshore wind farm layout. In Proceedings of the Power Electronics, Electrical Drives, Automation and Motion, Ischia, Italy, 11-13 June 2008; pp. 1470-1474.

115. Bresesti, P.; Kling, W.L.; Hendriks, R.L.; Vailati, R. HVDC connection of offshore wind farms to the transmission system. IEEE Trans. Energy Convers. 2007, 22, 37-43. [CrossRef]

116. Negra, N.B.; Todorovic, J.; Ackermann, T. Loss evaluation of HVAC and HVDC transmission solutions for large offshore wind farms. Electr. Power Syst. Res. 2006, 76, 916-927. [CrossRef]

117. Grady, S.A.; Hussaini, M.Y.; Abdullah, M.M. Placement of wind turbines using genetic algorithms. Renew. Energy 2005, 30, 259-270. [CrossRef]

118. Banos, R.; Manzano-Agugliaro, F.; Montoya, F.G.; Gil, C.; Alcayde, A.; Gómez, J. Optimization methods applied to renewable and sustainable energy: A review. Renew. Sustain. Energ. Rev. 2011, 15, 1753-1766. [CrossRef]

119. Mosetti, G.P.C.D.B.; Poloni, C.; Diviacco, B. Optimization of wind turbine positioning in large windfarms by means of a genetic algorithm. J. Wind Eng. Ind. Aerodyn. 1994, 51, 105-116. [CrossRef]

120. Ackermann, T. Transmission systems for offshore wind farms. In Wind Power in Power Systems; John Wiley \& Sons, Ltd.: Hoboken, NJ, USA, 2005; pp. 479-504.

121. Li, D.D.; He, C.; Fu, Y. Optimization of internal electric connection system of large offshore wind farm with hybrid genetic and immune algorithm. In Proceedings of the Electric Utility Deregulation and Restructuring and Power Technologies, Nanjing, China, 6-9 April 2008; pp. 2476-2481.

122. Ministerio de Industria, Turismo y Comercio-Ministerio de Medio Ambiente y Medio Rural y Marino. Available online: http://www.minetur.gob.es/es-es/gabineteprensa/notasprensa/documents/np\%20mapa\% 20e\%C3\%B3lico\%20marino\%2020\%2004\%2009.pdf (accessed on 10 December 2019).

123. De Alegría, I.M.; Andreu, J.; Martín, J.L.; Ibanez, P.; Villate, J.L.; Camblong, H. Connection requirements for wind farms: A survey on technical requierements and regulation. Renew. Sustain. Energ. Rev. 2007, 11, 1858-1872. [CrossRef]

124. Yang, J.; Fletcher, J.E.; O'Reilly, J. Multiterminal DC wind farm collection grid internal fault analysis and protection design. IEEE Trans. Power Deliv. 2010, 25, 2308-2318. [CrossRef]

125. Gomis-Bellmunt, O.; Liang, J.; Ekanayake, J.; King, R.; Jenkins, N. Topologies of multiterminal HVDC-VSC transmission for large offshore wind farms. Electr. Power Syst. Res. 2011, 81, 271-281. [CrossRef] 
126. Shin, J.S.; Kim, W.W.; Kim, J.O. Study on designing for inner grid of offshore wind farm. J. Clean Energy Technol. 2015, 3, 265-269. [CrossRef]

127. De Alegría, I.M.; Martín, J.L.; Kortabarria, I.; Andreu, J.; Ereño, P.I. Transmission alternatives for offshore electrical power. Renew. Sustain. Energ. Rev. 2009, 13, 1027-1038.

128. Flourentzou, N.; Agelidis, V.G.; Demetriades, G.D. VSC-based HVDC power transmission systems: An overview. IEEE Transactions on Power Electronics 2009, 24, 592-602. [CrossRef]

129. Xiang, D.; Ran, L.; Bumby, J.R.; Tavner, P.J.; Yang, S. Coordinated control of an HVDC link and doubly fed induction generators in a large offshore wind farm. IEEE Trans. Power Deliv. 2006, 21, 463-471. [CrossRef]

130. Meyer, C.; Hoing, M.; Peterson, A.; De Doncker, R.W. Control and design of DC grids for offshore wind farms. IEEE Trans. Ind. Appl. 2007, 43, 1475-1482. [CrossRef]

131. Bosch, J.; Staffell, I.; Hawkes, A.D. Global levelised cost of electricity from offshore wind. Energy 2019, 189, 116357. [CrossRef]

132. Maalawi, K.Y.; Negm, H.M. Optimal frequency design of wind turbine blades. J. Wind Eng. Ind. Aerodyn. 2002, 90, 961-986. [CrossRef]

133. Xudong, W.; Shen, W.Z.; Zhu, W.J.; Sørensen, J.N.; Jin, C. Shape optimization of wind turbine blades. Wind Energy 2009, 12, 781-803. [CrossRef]

134. Li, H.; Chen, Z.; Polinder, H. Optimization of multibrid permanent-magnet wind generator systems. IEEE Trans. Energy Convers. 2009, 24, 82-92. [CrossRef]

135. Park, J.; Kwon, S.-D.; Law, K. A Data-Driven, Cooperative Approach for Wind Farm Control: A Wind Tunnel Experimentation. Energies 2017, 10, 852. [CrossRef]

136. Jallad, J.; Mekhilef, S.; Mokhlis, H. Frequency Regulation Strategies in Grid Integrated Offshore Wind Turbines via VSC-HVDC Technology: A Review. Energies 2017, 10, 1244. [CrossRef]

(C) 2020 by the authors. Licensee MDPI, Basel, Switzerland. This article is an open access article distributed under the terms and conditions of the Creative Commons Attribution (CC BY) license (http://creativecommons.org/licenses/by/4.0/). 